Article

\title{
Looking for the Sustainability Messages of European Universities' Social Media Communication during the COVID-19 Pandemic
}

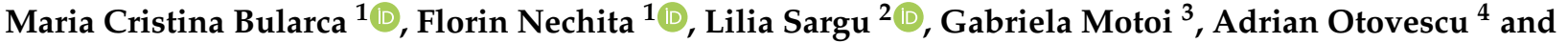 \\ Claudiu Coman $1, *$ (i)
}

1 Faculty of Sociology and Communication, Transilvania University of Brasov, 500036 Brașov, Romania; maria-cristina.bularca@student.unitbv.ro (M.C.B.); florin.nechita@unitbv.ro (F.N.)

2 Faculty of Economic Sciences, University of European Studies of Moldova, 2069 Chisinau, Moldova; lsargu@mail.ru

3 Faculty of Social Sciences, University of Craiova, 200585 Craiova, Romania; gabriela.motoi@edu.ucv.ro

4 Faculty of Letter, University of Craiova, 200585 Craiova, Romania; adrian.otovescu@edu.ucv.ro

* Correspondence: claudiu.coman@unitbv.ro

check for

updates

Citation: Bularca, M.C.; Nechita, F.;

Sargu, L.; Motoi, G.; Otovescu, A.;

Coman, C. Looking for the

Sustainability Messages of European

Universities' Social Media

Communication during the

COVID-19 Pandemic. Sustainability

2022, 14, 1554. https://doi.org/

$10.3390 /$ su14031554

Academic Editor: Paweł Bryła

Received: 29 December 2021

Accepted: 26 January 2022

Published: 28 January 2022

Publisher's Note: MDPI stays neutral with regard to jurisdictional claims in published maps and institutional affiliations.

Copyright: () 2022 by the authors Licensee MDPI, Basel, Switzerland. This article is an open access article distributed under the terms and conditions of the Creative Commons Attribution (CC BY) license (https:// creativecommons.org/licenses/by/ $4.0 /)$.

\begin{abstract}
Organizations in general, and higher education institutions in particular, had to face many challenges during the pandemic in order to carry out their usual activities. Since communications and interactions between universities and students were required to take place online, the messages sent by universities on their social media platforms held greater importance. In this regard, the purpose of the paper was to identify the promotion strategies used by European universities on Facebook and Instagram in the context of the COVID-19 pandemic. Thus, we were interested in identifying differences and similarities in the types of messages European universities sent on the two social networks, regarding the way they communicated about sustainability. The method used in order to conduct the research was content analysis, while having as an instrument a content analysis grid. We analyzed the activity of 20 European universities included in the World University Rankings 2021. The results of the research revealed that universities communicated more on Facebook than on Instagram, that the most frequent messages regarding sustainability were the ones about the actions carried out by universities in order to protect the environment, and that they registered a higher engagement rate on Instagram than on Facebook.
\end{abstract}

Keywords: university; online communication; sustainability messages; Facebook; Instagram

\section{Introduction}

The COVID-19 pandemic has generated changes in the way people and organizations used to interact, communicate, and carry out their daily activities. In the context of the pandemic, most communication processes between institutions and their members, as well as between institutions and their external audiences, took place exclusively online.

The virus was first detected in December 2019 in the Chinese city, Wuhan [1], and due to the large number of infected people, on 11 March 2020, the World Health Organization officially declared a Coronavirus pandemic [2]. In this regard, the pandemic affected not only the medical field, but also the economic, cultural, and educational fields.

Due to its direct impact on peoples' health, the pandemic indirectly influenced the way organizations operate, with many being forced to constantly adapt and improve their communication and promotion strategies. Thus, whether it took place internally, between the members of the organization, or externally, effective communication played an essential role during the pandemic [3].

As one of the consequences of the pandemic situation was the restriction of communication and face-to-face interaction, the online environment gained greater importance in the communication process both at the individual and organizational level. Although 
the online environment provided a variety of effective means of communications, during the pandemic, social media has become "an essential communication tool used by governments, organizations and universities to disseminate crucial information" [4]. Thus, one of the most relevant features of social networks in this context is the facilitation of the dissemination of information about policies and protocols implemented at local, regional, and international levels [5], and in order to understand the importance of these networks, more attention should be paid to what users do on the platforms rather than to the tools and options they integrate [6].

Furthermore, following the increase in the use of social networks, an increase of people's dependence on these platforms in order to relate to each other for professional, educational, and social purposes was observed during the pandemic [7]; thus, studying the activity of social media users has become even more important. In this regard, a study focusing on digital communication conducted in 2020 in the United States showed that 35\% of the participants of the study declared they used social networks more frequently than during the pre-pandemic period [8]. Even more, in the academic context, recent studies showed that more and more students use social media platforms to receive information about universities and their academic offer, with the percentage of those who used social networks for this purpose being 9\% in 2021, compared to 3\% in the year 2020 [9].

Hence, building a social media presence is essential for an organization today, and given that social platforms can help increase brand awareness, organizations could attract more customers through these platforms [10]. As well, social networks allow users to send personalized messages to a target audience, and recent studies showed that in the context of the stressful situation created by the pandemic, when consumers received personalized messages from a company, they tended to become more loyal to the company and that they appreciated more companies that took into consideration their needs and desires [11]. Moreover, previous studies revealed that leading universities from the United States whose activities focused on sustainability, rely on social media to reach their audience, and that sustainability leaders consider that social media strategies should pay attention to the characteristics of the audience, of "what's unique about them" [12].

Taking into account the educational field, higher education institutions had to communicate with students and potential students through their official online platforms, such as their websites and social networks pages. Since the online environment was the main communication channel used by universities, the way these institutions chose to send messages through it during the pandemic became very important for maintaining favorable relationships with students. In this regard, the purpose of our paper was to identify the promotion strategies used by European universities on Facebook and Instagram in the context of the COVID-19 pandemic. More precisely, we were interested in analyzing the sustainability messages sent on the two platforms by European universities and the types of messages they sent on their official Facebook and Instagram pages, but we were also interested in identifying differences and similarities between the content, format, and frequency of the posts made by universities on the two platforms.

Hence, in a society in which the online environment has become the main communication channel between individuals and between individuals and organizations, we argue that a study focusing on the way European universities choose to communicate and to promote themselves online is both relevant and necessary. During the pandemic, online platforms in general and social networks in particular represented the main contact point between universities, students, and potential students. In this regard, how universities decided to present their activity and the type of messages they intended to send to their audience was very important in order to maintain favorable relationships with current students and in order to arouse the interest of potential students in studying at a certain university. In this context, the possible practical implications of the paper could be represented by the fact that, by providing an overview of the communication strategies used by European universities on Facebook and on Instagram, the results of the research could be taken into account by other universities when elaborating their online promotion and communication 
strategies. Hence, while taking into account the results of the study, universities could differentiate the type of content posted on their official Facebook and Instagram pages in order to improve their communication strategies and their relationships with students and potential students, and they could focus more on promoting their sustainable activities. Another possible practical implication of the study refers to the fact that the instruments developed in order to conduct the research could be used in future studies that focus on the online interaction between universities and their stakeholders.

\section{Literature Review}

\subsection{Communication and Promotion on Social Networks}

Over time, the concept of promotion has been defined in many ways. In this regard, promotion can be understood as "any communication activity whose purpose is to move forward products, ideas or services in the marketing channel in order to reach the final consumer" [13] (p. 3). In a similar manner, while being a component of the marketing mix, promotion is seen as "a form of communication used to inform, convince or remind the public of the goods, services, image, and community involvement of a person or organization" [14] (p. 273).

The development of social networks "has revolutionized the way people communicate, socialize and share information with each other" [15] (p. 125). Today, the online environment and social networks have managed to eliminate communication barriers, such as geographic barriers, and as a result, individuals can communicate instantly and at any time with both close friends and acquaintances and with people they have not met in person [16]. Hence, social media and social networks are important elements that people pay special attention to, which is why organizations can no longer afford not to integrate them into their communication and promotion strategies, or to consider them tools that are intended only for the young generation [17]. In this regard, social networks are also essential in the communication process of higher education institutions, and since communicating with students or potential students through social media can sometimes be a challenge, in order to be able to interact effectively with them, universities should adopt strategies that focus on two-way communication [18].

In the context of the online communication of organizations, it is important for them to consider the current way in which they send information to the target audience, and to try to find answers to questions such as: "how does the public perceive the current way of communication?" and "what kind of strategy can determine positive behaviors and positive answers from the public?" [19]. Furthermore, considering that most companies focus their promotional activities around the idea of "creating unique content that users will appreciate and share" [20], there are several strategies that companies can adopt in order to create content. These strategies involve sending informative or persuasive messages separately, sending both informative and persuasive messages, carrying out communication actions whose purpose may be the direct selling of the product by clearly exposing the benefits it offers compared to the products made by competitors, or whose purpose may be indirect selling by presenting the characteristics of products or services in a more subtle way [21]. Other communication and promotion strategies involve building customer loyalty through special offers or rewards, or monitoring feedback from the public [22].

\subsubsection{Social Media versus Social Networks}

Broadly, the concept of social media is used to "describe collaborative media creation and sharing on a fairly large scale, including social networks and other platforms such as blogs, or podcasts" [23]. Thus, although the term social media is often used as a synonym for social networks, the definition previously mentioned reveals that social media encompasses social networks. Social media allows people to interact, describe, and selfpresent themselves in real time or in an asynchronous way to a broad and narrow public, and their value is derived from content generated by users and from the way they perceive their interaction with other users [24]. 
Due to its nature, social media offers users many opportunities for interaction, through tools such as chat boxes, private messages, videos, audio messages or group discussions [25]. One of the strengths of social media is the power to unite and bring together people with common interests. Hence, through social media, people with similar preferences for certain products or services of a company can socialize and pass on positive information about it, thus influencing the decision of other people to purchase those products [26].

Similar to the concept of social media, the concept of social networks has been defined in many ways. In this regard, social networks are considered "web-based services that allow individuals to create a public or semi-public profile within a bounded system, to articulate a list of other users with whom they share a connection, and to view and traverse their list of connections and those made by others within the system" [27] (p. 211). In a similar manner, social networks are seen as social structure of nodes which are represented by individuals or organizations, and at their basis usually stands the strength of the relationship and the trust between the users [28] (p. 225).

\subsubsection{Types of Social Networks and Their Characteristics}

The development of technology and the evolution of the Internet led to the diversification of communication channels in general, and of social networks in particular. Today, among the most popular and frequently used social networks are: Facebook, Twitter, Instagram, YouTube, Snapchat, Tumblr, and LinkedIn [29].

One of the main characteristics of these platforms is their participatory nature, which is closely related to interactivity, social networks offering users the opportunity to interact [30]. Other features are represented by integration, least effort-the ease with which users can communicate, and time effectiveness - the reduced time required for the communication process. Integration refers to the ability of social networks to connect an impressive number of users with various characteristics. Then, because people can use them for free without needing specific skills, social networks make it easier for them to communicate with each other, and they also allow users to send and receive messages instantly, at any time [31].

Considered the most popular social network today, since its launch Facebook has registered a significant number of users, and by 2020, according to the Digital 2020 report, Facebook remains the most-used social network in the world, with over 2.4 billion active users per month [32].

Facebook was created within the grounds of Harvard University by Mark Zuckerberg and it was launched in February 2004 [33]. Access to the platform was initially given only to the students of the university, but two years later, in 2006, people outside the university also had the opportunity to create an account [34]. People were delighted with the platform and the options it provided, and so Facebook grew rapidly, registering over 700,000 users in April 2004 [35].

Although Facebook is the platform most used worldwide, preferences can also be observed for social networks such as Instagram or YouTube. Instagram is a platform focused on visual content; it was launched in 2010, it is currently owned by Facebook, it allows users to post pictures and videos (which can be edited with the help of filters), other users can be tagged in them, and its specific symbol is the hashtag [36].

In this regard, a tendency for younger generations to use Instagram can be observed the Digital 2020 report showing that in 2020, Instagram registered over one billion active users per month, and most users were aged between 18 and 34 years old [32]. Furthermore, Instagram is a social network which is mostly used through the mobile app, and its popularity can be associated with the development of smartphones and their built-in cameras [37]. Given that Facebook and Instagram are two of the most popular social networks and that younger people, including potential students, are more orientated towards the use of Instagram, we focused our research on analyzing the activity of European universities on Facebook and Instagram. 


\subsection{The Use of Social Networks at Individual and Organizational Level}

Identifying the reasons and motives of the use of social networks by people and organizations has become a topic of interest for researchers, with the literature providing various information in this regard. Hence, a study conducted in India, on 1027 participants, showed that more than half of the respondents $(62.5 \%)$ considered that social networks are important tools in the communication process, and that $19 \%$ of participants considered that social networks are sources of information [38].

Regarding the organizational environment, a previous research study identified five main ways in which organizations use social networks. Firstly, social media platforms are used in order to send information in one way, without expecting feedback, then in order to dialogue, to manage information and share knowledge, but also to socialize, and to build friendships [39].

Social networks can also be used by companies to increase their brand awareness, to improve their image and reputation, to convince the public to be more involved in their activities, or to provide support and assistance for their customers [40]. Moreover, an organization that aims to maintain a favorable relation with its audiences can do so with the help of social networks, by creating communities in which people have the opportunity to exchange views on the organization's products or services [41]. In this regard, a previous study showed that the activity carried out on online platforms significantly influences the notoriety of companies. In other words, social networks can be used by organizations as a tool to improve their visibility and as a tool with which they can create easier associations in people's minds [42].

Considering the academic environment, previous studies were also interested in examining the use of social networks by students. Hence, a study focused on how students at the University of Applied Sciences in Amsterdam used social networks revealed that $70.2 \%$ of respondents used Facebook to search for and obtain information, and many students also used it in order to socialize and interact with other people, as well as for academic purposes [43]. A study conducted in Mexico showed that the main purpose for which students used social networks was entertainment, being followed by socializing, getting updates on the activity of their friends, and obtaining information [44].

Furthermore, a research study conducted in 2017 at the Michigan State University revealed similar results to those previously identified in terms of how students prefer to use Facebook, presenting main reasons for use as: entertainment, information gathering, interaction, and eliminating boredom, but it also highlighted reasons such as sending information and the expressing of their own ideas and opinions [45].

However, besides Facebook, students prefer to use other platforms too. A study that looked at what networks are most often used by students showed that Instagram was their favorite social network, with Facebook ranking third after Snapchat. The study thus highlights an orientation of students towards platforms focused on visual content [46].

In the case of higher education institutions, effective use of social networks requires universities to pay attention to how they send messages through these platforms so that the messages match the promises made by them to their audience, but it also requires universities to have the ability to address situations where certain messages reflect negatively on them [47].

Considering the use of social networks by universities, previous studies revealed interesting results. Hence, a study conducted in 2013, which analyzed the way Canadian universities communicate on Facebook and Twitter, identified three levels of activity: very active, moderately active, and low-activity universities, but also identified differences between the activities of the universities on the two platforms. According to the study, on Facebook, $24 \%$ of the universities analyzed were included in the very active category, while on Twitter, in the same category was included in $38 \%$ of the universities examined, which showed the fact that the institutions were more active on Twitter than on Facebook [48].

Regarding the universities' communication on Facebook, the results of two previous studies are noteworthy. The first study [49] analyzed the way 66 of the best ranked 
universities in the world in 2014, located in the United States of America, communicated on Facebook. The researchers focused on analyzing the format of the posts made on the official Facebook pages of the institutions, as well as on analyzing the number of likes, comments, and shares registered. Some of the results showed that the most frequently made posts were photo-type posts (56\%), while video posts were rarely used $(8 \%)$, but also that adding photos to a particular post may increase the level of interaction and engagement with that post [49].

In the second study [50], the researchers extended their research and focused on the type of posts depending on their content. Thus, among the categories in the analysis grid according to which their research was carried out were: campus posts, news/announcement posts, admission posts, academic events, research projects, or student achievements. Following the research, the results of the study highlighted the fact that there were certain types of posts that generate greater public involvement: posts about sports competitions, admission, or news [50].

Taking into account European universities, a previous study on the process of communication on social networks of universities from Lithuania, revealed that universities in that country follow each other on social platforms, that the main networks they use to communicate with the public are Facebook and YouTube, that students and potential students are more attracted to the visual content posted by universities, but also that the institutions do not involve effectively members of the academic community and internal departments in development of the online communication strategy [51]. Furthermore, the results of a study that examined the online presence of the best universities in the world in 2018, show that Facebook was the most-used social network [52].

Another study, which looked at the visual communication of 51 universities from the United Kingdom on Instagram, showed that their most frequent posts were in the category of photo posts whose purpose was to humanize the university, but also that the institutions posted rarely, once every three or four days, the average number of followers per institution being 1455, although in reality they registered a much higher number of students [53].

A previous study, which analyzed the activity on social networks of the top 10 universities in the world according to the QS-Quacquarelli Symonds University Ranking in 2017, on Instagram, the most common posts contained information about the university's achievements, on Twitter the posts were also about various articles presenting events organized by the institution, and on Facebook, the most popular posts were the posts accompanied by links, which send the user to their official websites. A common aspect in the communication of universities was represented by their tendency to make posts with mostly visual content, but also with emotional content such as posts about the results and performance of universities, about new ideas, studies, and inventions [54].

\section{The Use of Social Networks by Universities during the Pandemic}

The way universities communicated on social media in the context of the pandemic became a subject of interest for researchers. In this regard, a study which focused on the online communication of public and private universities in Cyprus [55], showed that among the posts of public universities that received the most interaction from users were posts with information about the development of the educational process online, about the position of universities in various rankings, but also posts that were accompanied by photos with the campus. The same study also highlighted that the use of social networks can contribute to the improvement of the universities' communication process and to the development of activities in a more sustainable manner, but it also showed that most of the posts of the four universities analyzed had visual content $(74.5 \%)$, and a percentage of $35.2 \%$ of the total posts had content related to the COVID-19 pandemic [55].

Another study, which examined the communication of King Abdulaziz University in Saudi Arabia on Twitter during the pandemic, found that the university used Twitter to convey information about changes in the educational process in order to encourage students to be productive during the pandemic, and that the flexibility that Twitter offers 
to the communication process helped maintain a positive relationship between members of the academic community [56].

\subsection{Advantages and Disadvantages of Communication and Promotion on Social Networks}

Due to the tools and options they integrate, social networks can facilitate the promotion and communication process of an organization. Hence, from the perspective of the advantages of social networks, it is beneficial for an organization to use such platforms because promotion through them either does not involve any costs or involves very low costs, and they allow the organization to communicate messages to a large number of people in a relatively short time and with minimal effort [57]. Another advantage of social networks is represented by the fact that they allow a two-way communication process. For example, Facebook allows companies to provide direct answers to people's questions and concerns, and through interactions with the public, companies can receive feedback on their current products or services, but also on products or services they want to develop in the future [58].

Furthermore, social networks also help to build a trust-based relationship between the organization and its audience. They also play a key role in increasing its visibility, with each post being able to be seen not only by customers but also by potential customers [59]. Other advantages of social networks include the possibility to not only establish connections with individuals that the user already knows, but also with new people, called social involvement-people and institutions having the opportunity to get involved socially and participate online in various activities, entertainment, and the fact that these platforms facilitate the process of obtaining new and interesting information [60].

Although social networks have many advantages, they also have some disadvantages. In the case of promotion on social networks, issues related to data privacy and security may arise, with many users being reluctant to engage in dialogues and interactions that involve the provision of personal data [61]. Other disadvantages and risks involve: too much time spent on these platforms; a psychological risk, which highlights the fact that the information posted on Facebook can be public information, which makes users more likely to receive negative feedback or comments from other users; and a social risk-of interacting with people online more than in reality [60].

Therefore, taking into account the aspects mentioned above, in the context of organization, one advantage of social networks is represented by the fact that they can be used as tools in the organization's process of communication and promotion. The costs of promotion on social networks are relatively low and such platforms can help the organization send messages to a large number of people, thus, to a large number of potential students. Moreover, social networks can help organizations maintain a favorable relationship with students and potential students because they offer organizations the possibility to answer to their questions.

From the perspective of the user, social networks help people keep in touch with each other and with the representatives of the institutions. Thus, users have the opportunity to follow their favorite organizations or public persons, to be up to date and aware of the activities they carry out, and social networks also offer users the opportunity to comment on the actions of the institutions, to offer them feedback.

Considering the disadvantages of social networks from the perspective of institutions, the feedback they can receive through people's comments can affect their image if the feedback is negative. From the perspective of the user, some of the disadvantages are represented by the fact that users can spend too much time on social networks, or they can start to communicate more online than face-to-face.

\subsection{Sustainability Issues in Universities' Communication Agenda}

Before looking at the way universities choose to promote and send sustainability messages, it is necessary to understand better the concepts of sustainable development and sustainability communication. In this regard, sustainable development was defined 
by the World Commission on Environment and Development as "the development that meets the needs of the present without compromising the ability of future generations to meet their needs" [62]. In this context, sustainability communication can be understood as a complex process which refers to the future development of society, at its basis standing "a vision of sustainability" [63]. Hence, sustainability communication implies a process of mutual understanding, of analyzing issues or possibilities of development, that takes place between people, between people and organizations, but also within organizations including universities [63].

The role of universities in creating and promoting a sustainable future was acknowledged and studied by many researchers [64-68], and barriers to sustainability were also revealed [69]. Furthermore, cooperation between industry and academia in the area of sustainability science [70], the ability to use media for communication sustainability issues [71,72]; or the lack of information and communication [73], may facilitate or become obstacles in the promotion of universities' sustainability initiatives among different stakeholders. In this regard, previous studies [65] stated that many universities are lagging behind companies in their attempt of creating a more sustainable society.

The studies and papers about the universities' engagement in the transformation of societies include research conducted in different context and parts of the world such as USA (Harvard University) [74], Spain [75,76], Italy [77], Sweden [78], Portugal [73], Lithuania [79], Romania [80], Brazil [81], China [82] and a multiple-country approach was also considered by researchers [83], who analyzed 1068 bachelor and master's degree programs in media and communication studies from 28 European countries.

The issues regarding communication challenges faced by universities in terms of their role and responsibility for increasing awareness, knowledge, skills, and values for creating a sustainable future are recurrent and they are related to:

1. Communicating through their websites $[77,79,84,85]$

2. Lack of internal communication $[65,76]$

3. Communication of the sustainable development as a sustainability assessment tool $[86,87]$

4. Developing competences for communicating into a globalized and interconnected world [71,72]

5. Communication strategy $[74,75,80]$

6. Improvement of the promotion models by including students and staff and creating bidirectional communication channels $[81,84,88]$;

7. Interpreting sustainability with a wider meaning and translating it to different stakeholders [89]

Regarding the use of social media tools as a way to engage stakeholders and the internal public in educating and promoting the universities' sustainable future and their role in building it, previous studies highlighted some interesting aspects. A previous study supported the idea that social media platforms could be seen by universities as new means of raising awareness about environmental sustainability among employees and students [90].

While focusing the research on the analysis of the activity on Facebook of University of Florence, (on both the official page and its dedicated channel for sustainability dissemination), during the entire year of 2019, a previous research revealed that most posts about sustainability fell into the category of community engagement, but also in the category of research, or teaching, and that the level of interaction between the university and its stakeholders was relatively low. The same study also highlighted the idea that engaging the stakeholders through social media platforms is still a challenge for the university analyzed, and that social media could be very useful for communicating with large audiences and for increasing the awareness of people about sustainability-related issues [91].

Another study which focused on the matter of sustainability messages sent on Twitter revealed that posts which had the hashtag "sustainability" were related to the idea of innovation, that companies which operate in the field of renewable energy acknowledged the essential role of communicating with their stakeholders, with them considering that 
social networks are appropriate platforms for two-way communication. The research also identified six areas of sustainability which were mostly approached on Twitter, such as: environmental sustainability, awareness about sustainability, renewable energy and climate change, innovative technology, green architecture, and food sustainability [92].

Furthermore, scholars who analyzed the content related to sustainability communicated on the websites of companies, non-profit organizations, and universities, showed that universities focused more than non-profit organizations did on sustainability messages, them having a section dedicated to sustainability on their websites. The same study also revealed that the issues most frequently discussed by the institutions analyzed in the context of sustainability, were about waste $(50 \%)$, energy $(48 \%)$, building $(45.3 \%)$ and water $(45.3 \%)[93]$.

\section{Material and Methods}

\subsection{Purpose and Objectives of the Research}

The purpose of the study was to identify the promotion strategies used by European universities on Facebook and Instagram in the context of the COVID-19 pandemic. In order to fulfil the purpose, we established a series of objectives. In this regard, the objectives of our research included:

O1. Identifying the type of content posted by the universities analyzed on their Facebook and Instagram accounts

O2. Identifying the type of format most often used by universities on their Facebook and Instagram accounts

O3. Identifying the frequency of the posts made by universities on Facebook and Instagram

O4. Identifying the universities which register more engagement from the public on Facebook and Instagram

O5. Identifying the frequency of the sustainability messages sent by universities on Facebook and Instagram

O6. Identifying differences and similarities in the promotion strategies of universities on Facebook and Instagram

\subsection{Hypotheses of the Research}

The hypotheses of the research are related to the results of previous studies conducted on the matter of online communication and promotion of universities.

Hypothesis 1. Universities have a higher frequency of posts on Facebook than on Instagram.

Hypothesis 1 is supported by a similar previous study in which Valerio-Ureña et al. [52] showed that Facebook was the social network most used by the universities analyzed.

Hypothesis 2. Universities register more engagement from the public on Instagram than on Facebook.

When we elaborated hypothesis two, we took into account the results of a study, in which Knight-McCord et al. [46], revealed that out of several platforms including Instagram and Facebook, Instagram was the platform most used by students. Thus, we inferred that students' preference for Instagram implies that they also interact and engage more with this social network than with other types of social networks.

Hypothesis 3. On Instagram, the most posted type of content is represented by student testimonials.

Hypothesis 3 is related to the results of a previous study conducted by Stuart et al. [53], on universities from the United Kingdom, which revealed that the posts most frequently made by the universities analyzed were posts whose aim was to humanize the institutions. Considering this result, we inferred that student testimonials can fall into the category 
of such posts, them having the power to humanize a university, by allowing students to present their authentic experiences.

Hypothesis 4. On Facebook, the most posted type of content is related to student counseling.

Hypothesis 4 is related to the results of a previous unpublished research of the authors, which showed that the universities analyzed posted frequent messages which contained advice for students. Moreover, given the pandemic context, we expected universities to have more posts regarding the way students could overcome the challenges they had to face during the pandemic.

Hypothesis 5. The post format most used on Facebook and on Instagram is the photo format.

Hypothesis 5 is supported by the results of a similar previous study [49], in which Peruta and Shields showed that the posts made most frequently by the universities fell into the category of photo type posts.

Hypothesis 6. Universities use different promotion strategies on Facebook and Instagram.

When we elaborated hypothesis 6 , we took into account the results of a research in which Maresova et al. [54] supported the idea that universities focus on different types of posts depending on the platform used.

\subsection{Sample}

The universities analyzed were selected from the ranking entitled World University Rankings 2021, elaborated by Times Higher Education, a ranking of the best universities in the world that includes more than 1500 universities from 93 countries and regions. In the ranking, up to the position 200, the position of each university is mentioned, and subsequently, the positions are presented according to the score obtained, in intervals: 201-250, 251-300, 301-350, 351-400, 401-500, 501-600, 601-800, 801-1000, 1001+ [94]).

The sample of our research comprised a total of 20 universities, and they have been selected according to several criteria. First of all, we chose European universities that had an active Facebook and Instagram account, and which had posts in English on these accounts, or which, in addition to the text in the language spoken in the country they belonged to, also had text written in English. Next, in order to have a more diverse sample, we chose the top five European universities present in the ranking regardless of the country of origin, then we chose the next 10 European universities, with the condition to choose only one university from each European country. After, we selected the top five universities in Romania included in the ranking. Hence, the sample includes five of the best ranked universities in the world in 2021, five of the best ranked Romanian universities, and wellranked universities from 13 European countries. In the context of these 13 universities chosen, we believe that the criteria we established, which referred to universities having both active Facebook and Instagram pages, having posts in English, and the criteria of choosing only one university from each European country, give relevance to the sample. Thus, we selected universities which were active on social media, and which tried to reach a large number of people by also posting in English and not only in the language of the country in which they were situated.

In this regard, the sample included the following universities: University of Oxford (position 1), University of Cambridge (position 6), Imperial College London (position 11), ETH Zurich (position 14), University College London (position 16), Technical University of Munich (position 41), KU-Leuven (position 45), Wageningen University \& Research (position 62), Lund University (position 103), Pompeu-Fabra University (position 152), Trinity College Dublin (position 155), University of Bologna (position 167), Technical University of Denmark (position 187), Aalto University (interval 201-250), University of Luxembourg (interval 201-250), Bucharest Academy of Economic Studies (interval 601-800), Babes-Bolyai 
University (position 1001+), University of Bucharest (position 1001+), "Alexandru Ioan Cuza" University of Iasi (position 1001+), and Transilvania University of Brasov (position 1001+). The selected universities come from countries such as: United Kingdom, Switzerland, Germany, Belgium, the Netherlands, Sweden, Spain, Ireland, Italy, Denmark, Finland, Luxembourg, and Romania. Furthermore, some of the universities we excluded because they did not meet the criteria of having Facebook and Instagram active pages and posts in English, are: LMU Munich, Karolinska Institute from Sweden, or Paris Sciences et Lettres PSL from France, which did not have posts in English.

\subsection{The Research Instrument}

The method used in order to conduct the research is content analysis, and the research instrument is represented by an analysis grid adapted from two grids used in previous studies that analyzed the way universities use their Facebook pages to promote themselves. The first part of the grid contains adapted categories related to the content of the posts [50] such as: student achievements, news and announcements, research projects, admission, academic conferences, entertainment, competitions, campus. To these categories we added other categories specific to this research, such as: COVID-19 information, vaccine information, city posts, sustainable development, and university achievements.

The second part of the grid contains adapted categories related to the format of the posts: photo, link to own site, external link, own video, external video, to which were added formats such as: share of associated page, share of unassociated pages, gif and boomerang. The third part of the grid contains criteria regarding the performance of universities: average number of posts/day, average number of reactions/post, average number of comments/post, average number of distributions/post, average number of views/videos, and total number of likes on page [49].

The analysis grid contains 28 categories related to the content of posts, nine categories related to the format of the post, and six categories related to the performance of universities. The text of the categories that were taken from the two grids used in previous studies can be found in the grid used in this research, written in italics. The research instrument used to conduct the research can be found in Appendix A.

\subsection{Procedure}

The activity on Facebook and Instagram of the selected universities was analyzed over a period of 1 month: April 2021. A total of 1005 posts were analyzed: 700 on Facebook and 305 on Instagram. In order to establish the analysis period, we took into account the fact that there may be differences in the way the academic year is structured in the case of the universities selected. Thus, we chose to examine the activity of universities in April 2021, because some universities have several admission sessions and start the semester either in October, in February, or in March, and this could have altered the results of the research, and April is a month in which all universities selected were in full swing.

While conducting the research, each post made by universities on their official Facebook and Instagram accounts was assigned to a category in the grid, in terms of content and format, and for each university we also calculated its performance indicators, expressed by number of likes (reactions), comments, and distributions. Thus, noting that certain posts may correspond to both a link format and a video format, as a rule, we considered that a post can be assigned to only one type of format and only one type of content.

Then, taking into account the fact that certain formats may generate different levels of engagement, in order to comply with the above rule, in cases where a post can fall into more categories of formats, we established a priority order.

In order to establish the order of priorities, we considered the results of a previous study which showed that posts which contain photos generate more interaction from the public than postings whose format is in link or video [49], as well as the results of a study which showed that including a link in a post led to a lower level of interaction than the level of interaction that the post would have if it did not contain a link [50]. 
In regards to the photo or link format of posts made on Facebook, only those posts in which the photo was uploaded directly by the university were included in the photo format, and not if the university had a post that contained a link, in which there was an article with a photo, and the platform automatically took the photo of the article, which is why it also appeared on the post. In other words, the posts were assigned to the photo format only if the post contained a photo uploaded/posted directly by the university.

In order to calculate the level of engagement for each university on Facebook and Instagram, we used a formula previously used in a similar study [49]. According to the formula, the post engagement is calculated by adding the numbers of likes, comments, and shares of the post, and then the number obtained is divided by the page likes at the end of the research. Moreover, since Instagram does not register the number of shares, in order to calculate the level of engagement of universities on this platform, we used the formula described above, but without the number of shares.

\section{Results}

\section{According to the Objectives of the Research and the Hypotheses of the Research}

O1. Identifying the type of content posted by the universities analyzed on their Facebook and Instagram accounts.

The analysis of the activity on Facebook of the 20 universities included in the research can be found in Appendix B and the analysis of the activity on Instagram of the 20 universities included in the research can be found in Appendix C.

Hence, the results of the research revealed that the most common type of content posted by universities on Facebook is the one about news and announcements (132 posts), followed by posts about research projects ( 80 posts), events ( 74 posts), admission ( 52 posts), pandemic context information (51 posts): virus information (27 posts) and vaccine information (24 posts), but also posts on sustainable development actions (41 posts), career guidance (22 posts) and competitions (22 posts). Frequent posts were also made about holiday wishes (27), but the analysis did not focus on them, as they are contextual and particular posts that would have altered the results of the research, because the holidays are distributed differently throughout the year. During the analyzed period there were several holidays, which is why these posts are also present in a larger number on the two platforms analyzed, but in another period it may not be possible for universities to include these posts in their strategy. Table 1 presents the number of posts made by the 20 universities analyzed on Facebook and Instagram, depending on the type of content.

On Instagram, the content most frequently posted is the one about related institutions and related spaces (32), followed by student testimonials (30), news and announcements (28), city posts (22), pandemic context information (21): virus information (11) and vaccine information (10), sustainable development actions (20), campus (20), and admission (19). Posts about holiday wishes are also common on Instagram (17), but the analysis did not focus on them because they are contextual and it is possible for universities to not have the opportunity to make such posts in another period.

Table 1. Analysis of the activity on Facebook and Instagram for the 20 universities included in the research depending on the type of content.

\begin{tabular}{cccc}
\hline $\begin{array}{c}\text { 1. Categories Referring to } \\
\text { the Type of Content }\end{array}$ & $\begin{array}{c}\text { Total Posts on Facebook for } \\
\text { the 20 Universities Analyzed }\end{array}$ & $\begin{array}{c}\text { Total Posts on Instagram for } \\
\text { the 20 Universities Analyzed }\end{array}$ & $\begin{array}{c}\text { Total Posts } \\
\text { Facebook + Instagram }\end{array}$ \\
\hline Information about COVID-19 & $27(3.85 \%)$ & $11(3.6 \%)$ & $38(3.78 \%)$ \\
\hline Information about vaccine & $24(3.42 \%)$ & $10(3.27 \%)$ & $34(3.38 \%)$ \\
\hline Events & $74(10.57 \%)$ & $14(4.59 \%)$ & $88(8.75 \%)$ \\
\hline University achievements & $17(2.42 \%)$ & $4(1.31 \%)$ & $21(2.89 \%)$ \\
\hline Competitions & $22(3.14 \%)$ & $9(2.95 \%)$ & $31(3.84 \%)$ \\
\hline Research & $80(11.42 \%)$ & $11(3.6 \%)$ & $91(9.54 \%)$ \\
\hline
\end{tabular}


Table 1. Cont.

\begin{tabular}{|c|c|c|c|}
\hline $\begin{array}{l}\text { 1. Categories Referring to } \\
\text { the Type of Content }\end{array}$ & $\begin{array}{l}\text { Total Posts on Facebook for } \\
\text { the } 20 \text { Universities Analyzed }\end{array}$ & $\begin{array}{l}\text { Total Posts on Instagram for } \\
\text { the } 20 \text { Universities Analyzed }\end{array}$ & $\begin{array}{c}\text { Total Posts } \\
\text { Facebook + Instagram }\end{array}$ \\
\hline Research about COVID-19 & $10(1.4 \%)$ & $3(0.98 \%)$ & $13(1.29 \%)$ \\
\hline Admission & $52(7.42 \%)$ & $19(6.22 \%)$ & $71(7.06 \%)$ \\
\hline Community involvement & $5(0.71 \%)$ & $1(0.32 \%)$ & $6(0.59 \%)$ \\
\hline News and announcements & $132(18.85 \%)$ & $28(9.18 \%)$ & $160(15.92 \%)$ \\
\hline Entertainment & $13(1.85 \%)$ & $11(3.6 \%)$ & $24(2.38 \%)$ \\
\hline Students' achievements & $21(3 \%)$ & $10(3.27 \%)$ & $31(3.08 \%)$ \\
\hline Graduates' achievements & $6(0.85 \%)$ & $2(0.65 \%)$ & $8(0.79 \%)$ \\
\hline Teachers' achievements & $19(2.71 \%)$ & $7(2.29 \%)$ & $26(2.58 \%)$ \\
\hline Connex institutions/spaces & $18(2.57 \%)$ & $32(10.49 \%)$ & $50(4.97 \%)$ \\
\hline Study/internship mobilities & $3(0.42 \%)$ & 0 & $3(0.29 \%)$ \\
\hline Webinars & $17(2.42 \%)$ & $1(0.32 \%)$ & $18(1.79 \%)$ \\
\hline Student counselling & $14(2 \%)$ & $13(4.26 \%)$ & $27(2.68 \%)$ \\
\hline Academic conferences & $7(1 \%)$ & $2(0.65 \%)$ & $9(0.89 \%)$ \\
\hline Career guidance & $22(3.14 \%)$ & $1(0.32 \%)$ & $23(2.28 \%)$ \\
\hline Posts about the city & $14(2 \%)$ & $22(7.21 \%)$ & $36(3.58 \%)$ \\
\hline Campus & $11(1.57 \%)$ & $20(6.55 \%)$ & $31(3.08 \%)$ \\
\hline Sustainability messages & $41(5.85 \%)$ & $20(6.55 \%)$ & $61(6.06 \%)$ \\
\hline Students' testimonials & $11(1.57 \%)$ & $30(9.83 \%)$ & $41(4.07 \%)$ \\
\hline Teachers' testimonials & $1(0.14 \%)$ & $3(0.98 \%)$ & $4(0.39 \%)$ \\
\hline Podcast & $11(1.57 \%)$ & $3(0.98 \%)$ & $14(1.3 \%)$ \\
\hline Thank you messages & $1(0.14 \%)$ & $1(0.32 \%)$ & $2(0.19 \%)$ \\
\hline Wishes & $27(3.85 \%)$ & $17(5.5 \%)$ & $53(5.27)$ \\
\hline Total & 700 & 305 & 1005 \\
\hline
\end{tabular}

O2. Identifying the type of format most often used by universities on their Facebook and Instagram accounts.

Given the activity on Facebook of the 20 universities included in the research, the most frequently used format is the photo format (299), followed by a link to their official websites (217), and its own video (86). The external link (52) and, to a lesser extent, the share of associated pages (33) were also used often.

On Instagram, universities used most frequently the photo format (245), followed by the own video format (59). At the same time, the gif format was used only in one post and the boomerang format only in one post too (Table 2 and Figure 1).

Table 2. Analysis of the activity on Facebook and Instagram for the 20 universities included in the research depending on the type of format.

\begin{tabular}{cccc}
\hline $\begin{array}{c}\text { 2. Categories Referring to } \\
\text { the Format of the Posts }\end{array}$ & $\begin{array}{c}\text { Total Posts on Facebook for } \\
\text { the 20 Universities Analyzed }\end{array}$ & $\begin{array}{c}\text { Total Posts on Instagram for } \\
\text { the 20 Universities Analyzed }\end{array}$ & $\begin{array}{c}\text { Total Posts } \\
\text { Facebook + Instagram }\end{array}$ \\
\hline Link to the official website & $217(31 \%)$ & - & $217(21.59 \%)$ \\
\hline External link & $52(7.42 \%)$ & - & $52(5.17 \%)$ \\
\hline Own video & $86(12.28 \%)$ & $59(19.34 \%)$ & $145(14.42 \%)$ \\
\hline
\end{tabular}


Table 2. Cont.

\begin{tabular}{cccc}
\hline $\begin{array}{c}\text { 2. Categories Referring to } \\
\text { the Format of the Posts }\end{array}$ & $\begin{array}{c}\text { Total Posts on Facebook for } \\
\text { the 20 Universities Analyzed }\end{array}$ & $\begin{array}{c}\text { Total Posts on Instagram for } \\
\text { the 20 Universities Analyzed }\end{array}$ & $\begin{array}{c}\text { Total Posts } \\
\text { Facebook + Instagram }\end{array}$ \\
\hline External video & $1(0.14 \%)$ & - & $1(0.09 \%)$ \\
\hline Photo & $299(42.71 \%)$ & $244(80 \%)$ & $543(54.02 \%)$ \\
\hline Share of associated pages & $33(4.71 \%)$ & - & $33(3.28 \%)$ \\
\hline Share of unassociated pages & $12(1.71 \%)$ & $1(0.32 \%)$ & $12(1.19 \%)$ \\
\hline Gif & - & $1(0.32 \%)$ & $1(0.09 \%)$ \\
\hline Boomerang & - & 305 & $1(0.09 \%)$ \\
\hline Total & 700 & 1005 \\
\hline
\end{tabular}

Hence, while taking into account the data from Table 2, the results referring to the type of format mostly used by the universities analyzed on Facebook and on Instagram, are represented visually in Figure 1.

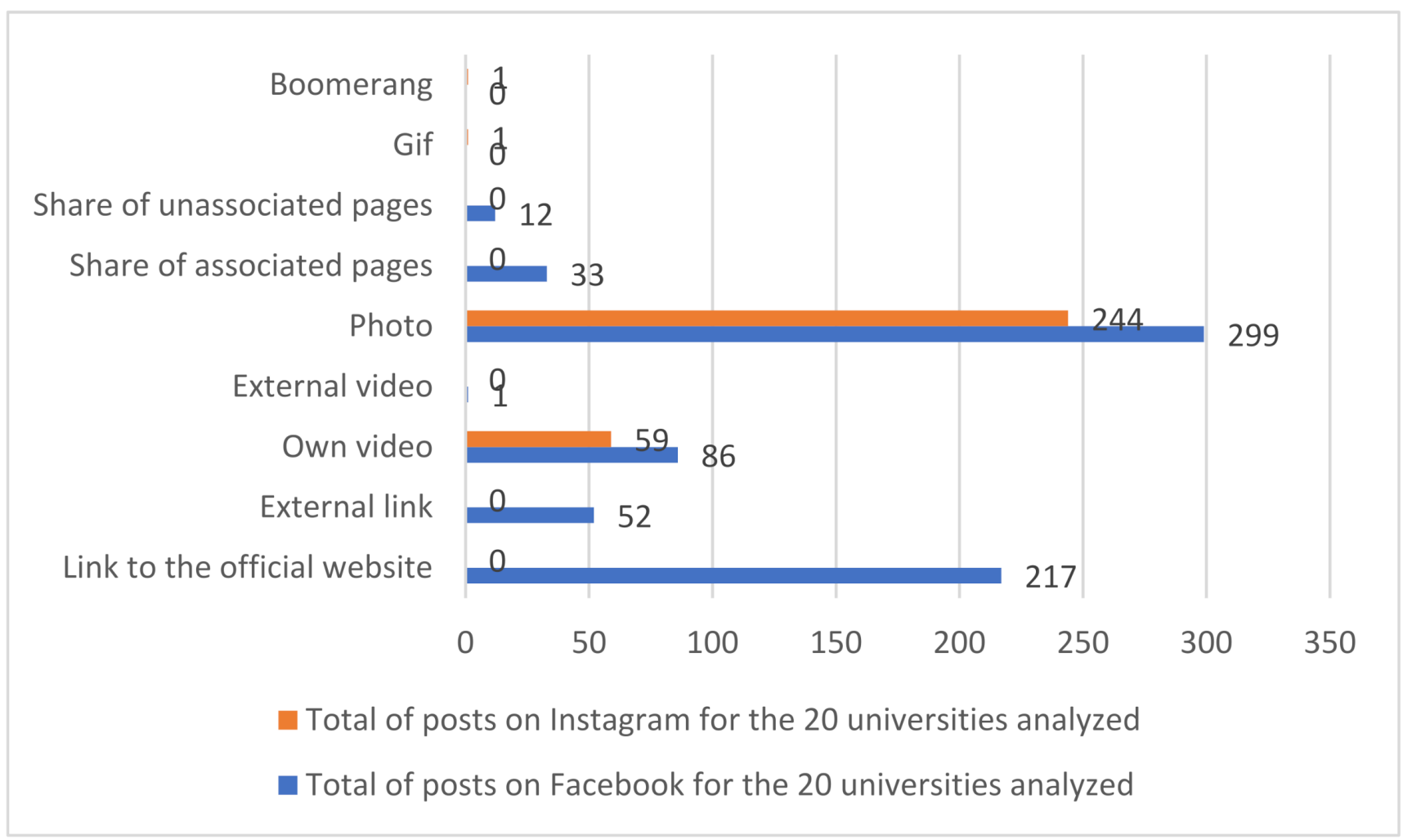

Figure 1. Type of post format used by universities on Instagram and Facebook.

O3. Identifying the frequency of the posts made by universities on Facebook and Instagram.

The universities analyzed posted more frequently on Facebook, with them having an average of 1.1 posts / day, while on Instagram, universities had an average of 0.5 posts per day (Table 3). Furthermore, both on Facebook and Instagram, the university that posted more often was University of Oxford. 
Table 3. Analysis of the activity on Facebook and Instagram for the 20 universities included in the research depending on the performance indicators.

\begin{tabular}{cccc}
\hline $\begin{array}{c}\text { 3. Categories Referring } \\
\text { to Performance }\end{array}$ & $\begin{array}{c}\text { Total Posts on Facebook for } \\
\text { the 20 Universities Analyzed }\end{array}$ & $\begin{array}{c}\text { Total Posts on Instagram for } \\
\text { the 20 Universities Analyzed }\end{array}$ & $\begin{array}{c}\text { Total Posts } \\
\text { Facebook + Instagram }\end{array}$ \\
\hline $\begin{array}{c}\text { Medium nr. of posts/day for } \\
\text { the } 20 \text { univ. analyzed }\end{array}$ & 1.1 posts/day & 0.5 posts/day & 1.6 posts/day \\
\hline $\begin{array}{c}\text { Medium nr. of reactions/post } \\
\text { (like, love, happy, sad) }\end{array}$ & 131.55 reactions/post & 1870.44 appreciations/post & $\begin{array}{c}2001.99 \text { reac- } \\
\text { tions /appreciations/posts }\end{array}$ \\
\hline $\begin{array}{c}\text { Medium nr. of } \\
\text { comments/post }\end{array}$ & 5.6 comments/post & 16.87 comments/post & 22.47 comments/post \\
\hline $\begin{array}{c}\text { Medium nr. of shares/post } \\
\text { Medium nr. of } \\
\text { views/video post }\end{array}$ & 11.28 shares/post & 4169.89 views/video post & 8212.12 views/video posts \\
\hline $\begin{array}{c}\text { Medium nr. of page } \\
\text { likes/of followers }\end{array}$ & $413,740.8$ page likes & $129,031.5$ followers & $542,772.3$ page likes/followers \\
\hline
\end{tabular}

O4. Identifying the universities which register more engagement from the public on Facebook and Instagram.

All the universities analyzed registered more engagement on Instagram than on Facebook (Tables 4-7). One possible explanation for the higher engagement rate on Instagram would be that since the universities' audiences are represented mostly by young people, and since it is known that young people are more orientated towards visual content, and thus they react more on the posts made by universities on Instagram.

On Facebook, the university with the highest level of engagement is the Academy of Economic Studies in Bucharest (0.13), followed by Babes-Bolyai University (0.09) and Trinity College London (0.08). On Instagram, the university with the highest level of engagement is the Academy of Economic Studies in Bucharest (0.9), followed by Wageningen University \& Research (0.72), and the Technical University of Munich (0.69).

Table 4. The level of engagement on Facebook and Instagram for the first 10 universities analyzed.

\begin{tabular}{ccccccccccc}
\hline Facebook & $\begin{array}{c}\text { Univ. } \\
\text { Ox. }\end{array}$ & $\begin{array}{c}\text { Univ. } \\
\text { Cam. }\end{array}$ & ICL & ETH & UCL & $\begin{array}{c}\text { TU } \\
\text { Mun. }\end{array}$ & $\begin{array}{c}\text { KU } \\
\text { Leuv. }\end{array}$ & $\begin{array}{c}\text { Wag. } \\
\text { Univ. }\end{array}$ & $\begin{array}{c}\text { Lund } \\
\text { Univ. }\end{array}$ & UPF \\
\hline Engagement & 0.019 & 0.007 & 0.013 & 0.02 & 0.004 & 0.016 & 0.006 & 0.019 & 0.010 & 0.001 \\
\hline \multirow{2}{*}{ Instagram } & $\begin{array}{c}\text { Univ. } \\
\text { Ox. }\end{array}$ & $\begin{array}{c}\text { Univ. } \\
\text { Cam. }\end{array}$ & ICL & ETH & UCL & $\begin{array}{c}\text { TU } \\
\text { Mun. }\end{array}$ & $\begin{array}{c}\text { KU } \\
\text { Leuv. }\end{array}$ & $\begin{array}{c}\text { Wag. } \\
\text { Univ. }\end{array}$ & $\begin{array}{c}\text { Lund } \\
\text { Univ. }\end{array}$ & UPF \\
\hline Engagement & 0.43 & 0.33 & 0.22 & 0.16 & 0.11 & 0.69 & 0.06 & 0.72 & 0.46 & 0.3 \\
\hline
\end{tabular}

In order to provide a clearer understanding of the differences between the engagement rates registered by the universities analyzed on Facebook and Instagram, we normalized the scores presented in Table 4, by multiplying each score by 100 . The normalized scores for the first 10 universities analyzed can be found in Table 5. Furthermore, in Figure 2 we represent the data from Table 5, regarding the engagement rate of the universities on Facebook and Instagram. 
Table 5. The level of engagement on Facebook and Instagram for the first 10 universities analyzed, multiplied by 100 .

\begin{tabular}{ccccccccccc}
\hline Facebook & $\begin{array}{c}\text { Univ. } \\
\text { Ox. }\end{array}$ & $\begin{array}{c}\text { Univ. } \\
\text { Cam. }\end{array}$ & ICL & ETH & UCL & $\begin{array}{c}\text { TU } \\
\text { Mun. }\end{array}$ & $\begin{array}{c}\text { KU } \\
\text { Leuv. }\end{array}$ & $\begin{array}{c}\text { Wag. } \\
\text { Univ. }\end{array}$ & $\begin{array}{c}\text { Lund } \\
\text { Univ. }\end{array}$ & UPF \\
\hline Engagement & 1.9 & 0.7 & 1.3 & 2 & 0.4 & 1.6 & 0.6 & 1.9 & 1 & 0.1 \\
\hline \multirow{2}{*}{ Instagram } & $\begin{array}{c}\text { Univ. } \\
\text { Ox. }\end{array}$ & $\begin{array}{c}\text { Univ. } \\
\text { Cam. }\end{array}$ & ICL & ETH & UCL & $\begin{array}{c}\text { TU } \\
\text { Mun. }\end{array}$ & $\begin{array}{c}\text { KU } \\
\text { Leuv. }\end{array}$ & $\begin{array}{c}\text { Wag. } \\
\text { Univ. }\end{array}$ & $\begin{array}{c}\text { Lund } \\
\text { Univ. }\end{array}$ & UPF \\
\hline Engagement & 43 & 33 & 22 & 16 & 11 & 69 & 6 & 72 & 46 & 30 \\
\hline
\end{tabular}

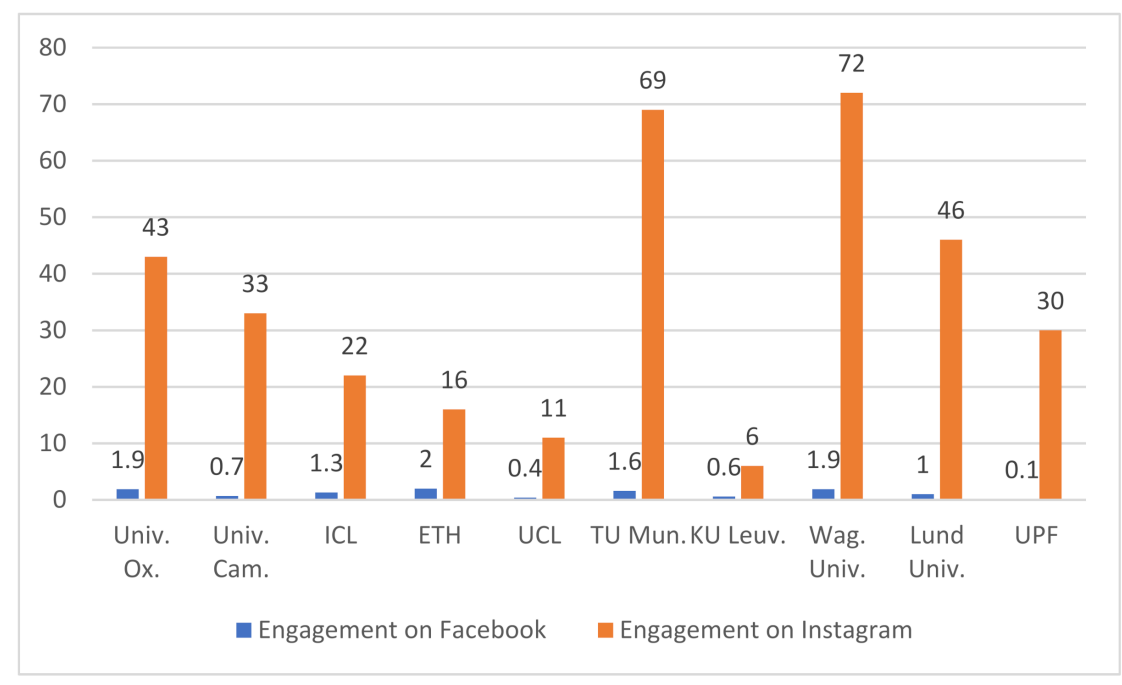

Figure 2. Engagement rate on Facebook and Instagram for the first 10 universities analyzed—normalized scores.

Table 6. The level of engagement on Facebook and Instagram for the next 10 universities analyzed.

\begin{tabular}{|c|c|c|c|c|c|c|c|c|c|c|}
\hline Facebook & TCD & $\begin{array}{l}\text { Univ. } \\
\text { Bolog. }\end{array}$ & $\begin{array}{l}\text { TU- } \\
\text { Den. }\end{array}$ & $\begin{array}{l}\text { Aalto } \\
\text { Univ. }\end{array}$ & $\begin{array}{l}\text { Univ. } \\
\text { Lux. }\end{array}$ & ASE & UBB & $\begin{array}{l}\text { Uni- } \\
\text { Buc. }\end{array}$ & $\begin{array}{l}\text { Uaic } \\
\text { Iași }\end{array}$ & Unitbv \\
\hline Engagement & 0.08 & 0.06 & 0.05 & 0.014 & 0.02 & 0.13 & 0.09 & 0.02 & 0.02 & 0.07 \\
\hline Instagram & TCD & $\begin{array}{l}\text { Univ. } \\
\text { Bolog. }\end{array}$ & $\begin{array}{l}\text { TU- } \\
\text { Den. }\end{array}$ & $\begin{array}{l}\text { Aalto } \\
\text { Univ. }\end{array}$ & $\begin{array}{l}\text { Univ. } \\
\text { Lux. }\end{array}$ & ASE & UBB & $\begin{array}{l}\text { Uni- } \\
\text { Buc. }\end{array}$ & $\begin{array}{l}\text { Uaic } \\
\text { Iași }\end{array}$ & Unitbv \\
\hline Engagement & 0.5 & 0.6 & 0.24 & 0.35 & 0.12 & 0.9 & 0.13 & 0.29 & 0.08 & 0.2 \\
\hline
\end{tabular}

The normalized scores for engagement rates on Facebook and Instagram of the next 10 universities analyzed are represented in Table 7, and their visual representation is provided in Figure 3. Thus, Figures 2 and 3 show that for all 20 universities, the engagement rate was higher on Instagram than on Facebook.

Table 7. The level of engagement on Facebook and Instagram for the next 10 universities analyzed, multiplied by 100 .

\begin{tabular}{|c|c|c|c|c|c|c|c|c|c|c|}
\hline Facebook & TCD & $\begin{array}{l}\text { Univ. } \\
\text { Bolog. }\end{array}$ & $\begin{array}{l}\text { TU- } \\
\text { Den. }\end{array}$ & $\begin{array}{l}\text { Aalto } \\
\text { Univ. }\end{array}$ & $\begin{array}{l}\text { Univ. } \\
\text { Lux. }\end{array}$ & ASE & UBB & $\begin{array}{l}\text { Uni- } \\
\text { Buc. }\end{array}$ & $\begin{array}{l}\text { Uaic } \\
\text { Iași }\end{array}$ & Unitbv \\
\hline Engagement & 8 & 6 & 5 & 1.4 & 2 & 13 & 9 & 2 & 2 & 7 \\
\hline Instagram & TCD & $\begin{array}{l}\text { Univ. } \\
\text { Bolog. }\end{array}$ & $\begin{array}{l}\text { TU- } \\
\text { Den. }\end{array}$ & $\begin{array}{l}\text { Aalto } \\
\text { Univ. }\end{array}$ & $\begin{array}{l}\text { Univ. } \\
\text { Lux. }\end{array}$ & ASE & UBB & $\begin{array}{l}\text { Uni- } \\
\text { Buc. }\end{array}$ & $\begin{array}{l}\text { Uaic } \\
\text { Iași }\end{array}$ & Unitbv \\
\hline Engagement & 50 & 60 & 24 & 35 & 12 & 90 & 13 & 29 & 8 & 20 \\
\hline
\end{tabular}




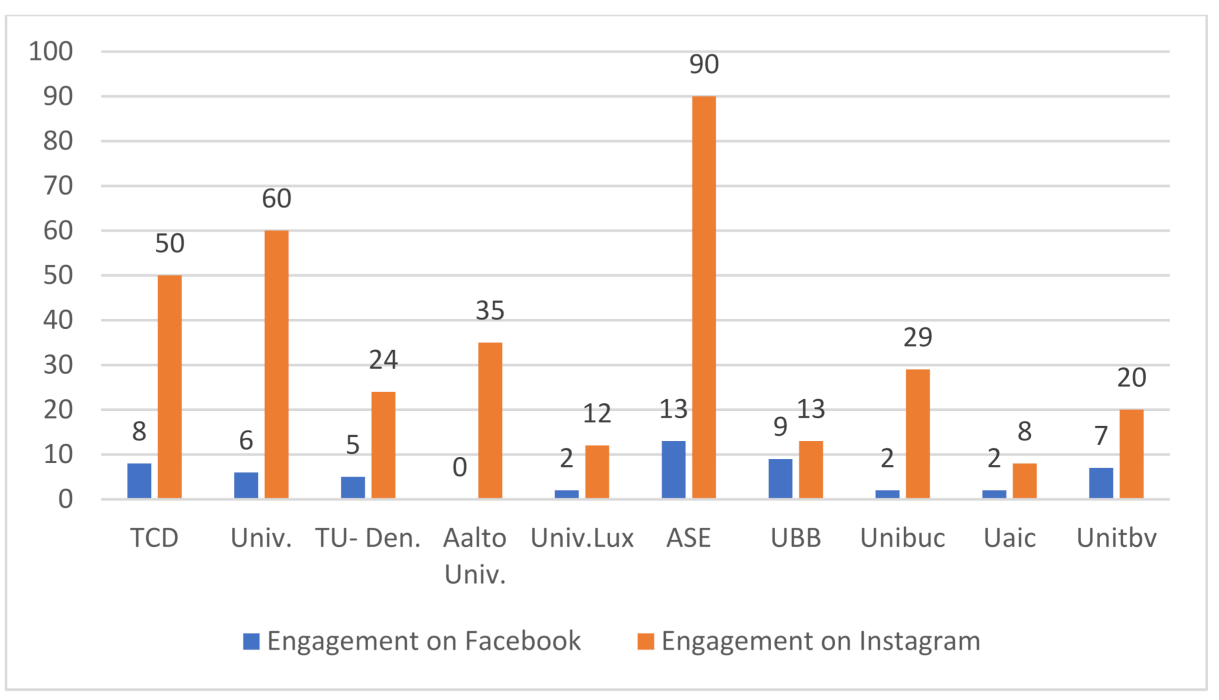

Figure 3. Engagement rate on Facebook and Instagram for the next 10 universities analyzed—normalized scores.

O5. Identifying the frequency of the sustainability messages sent by universities on Facebook and Instagram.

The results of the research revealed that on Facebook, the university which posted most frequently messages regarding their sustainability actions was KU-Leuven (0.83), it being followed by University of Oxford (0.33) and by Technical University Munich (0.15).

On Instagram, the highest frequency of posts about sustainable actions was registered by Aalto University (0.35), it being followed by University of Bologna (0.16) and KU-Leuven and Technical University Munich (0.12) (Tables 8 and 9).

Generally, the European universities analyzed posted similarly about their sustainable actions on Facebook and Instagram, but the results of the research showed that University of Cambridge, ETH Zurich, University of Bologna and Aalto University promoted their sustainable actions more on Instagram.

Table 8. The frequency of sustainability posts on Facebook and Instagram for the first 10 universities analyzed.

\begin{tabular}{ccccccccccc}
\hline Facebook & $\begin{array}{c}\text { Univ. } \\
\text { Ox. }\end{array}$ & $\begin{array}{c}\text { Univ. } \\
\text { Cam. }\end{array}$ & ICL & ETH & UCL & $\begin{array}{c}\text { TU } \\
\text { Mun. }\end{array}$ & $\begin{array}{c}\text { KU } \\
\text { Leuv. }\end{array}$ & $\begin{array}{c}\text { Wag. } \\
\text { Univ. }\end{array}$ & $\begin{array}{c}\text { Lund } \\
\text { Univ. }\end{array}$ & UPF \\
\hline $\begin{array}{c}\text { Frequency of } \\
\text { sustainability posts }\end{array}$ & 0.33 & - & - & 0.04 & - & 0.15 & 0.83 & 0.12 & 0.06 & - \\
\hline Instagram & $\begin{array}{c}\text { Univ. } \\
\text { Ox. }\end{array}$ & $\begin{array}{c}\text { Univ. } \\
\text { Cam. }\end{array}$ & ICL & ETH & UCL & $\begin{array}{c}\text { TU } \\
\text { Mun. }\end{array}$ & $\begin{array}{c}\text { KU } \\
\text { Leuv. }\end{array}$ & $\begin{array}{c}\text { Wag. } \\
\text { Univ. }\end{array}$ & $\begin{array}{c}\text { Lund } \\
\text { Univ. }\end{array}$ & UPF \\
\hline $\begin{array}{c}\text { Frequency of } \\
\text { sustainability posts }\end{array}$ & 0.04 & 0.03 & - & 0.06 & - & 0.12 & 0.12 & 0.08 & - & - \\
\hline
\end{tabular}

Table 9. The frequency of sustainability posts on Facebook and Instagram for the next 10 universities analyzed.

\begin{tabular}{ccccccccccc}
\hline Facebook & TCD & $\begin{array}{c}\text { Univ. } \\
\text { Bolog. }\end{array}$ & $\begin{array}{c}\text { TU- } \\
\text { Den. }\end{array}$ & $\begin{array}{c}\text { Aalto } \\
\text { Univ. }\end{array}$ & $\begin{array}{c}\text { Univ. } \\
\text { Lux. }\end{array}$ & ASE & UBB & $\begin{array}{c}\text { Uni- } \\
\text { Buc. }\end{array}$ & $\begin{array}{c}\text { Uaic } \\
\text { Iași }\end{array}$ & Unitbv \\
\hline $\begin{array}{c}\text { Frequency of } \\
\text { sustainability posts }\end{array}$ & - & 0.15 & 0.03 & 0.17 & 0.08 & - & 0.05 & - & - & - \\
\hline Instagram & TCD & $\begin{array}{c}\text { Univ. } \\
\text { Bolog. }\end{array}$ & $\begin{array}{c}\text { TU- } \\
\text { Den. }\end{array}$ & $\begin{array}{c}\text { Aalto } \\
\text { Univ. }\end{array}$ & $\begin{array}{c}\text { Univ. } \\
\text { Lux. }\end{array}$ & ASE & UBB & $\begin{array}{c}\text { Uni- } \\
\text { Buc. }\end{array}$ & $\begin{array}{c}\text { Uaic } \\
\text { Iași }\end{array}$ & Unitbv \\
\hline $\begin{array}{c}\text { Frequency of } \\
\text { sustainability posts }\end{array}$ & - & 0.16 & - & 0.352 & - & - & - & - & - & - \\
\hline
\end{tabular}


Taking into account the results of the research, the most frequent types of post regarding sustainability were the ones in which universities promoted the actions carried out in order to protect the environment, actions such as going net zero or recycling. For example, University of Oxford made posts on Facebook in which it promotes its plan to go net zero, and University of Bologna posted on Facebook regarding its sustainable actions such as developing a zero-emission boat.

O6. Identifying differences and similarities in the promotion strategies of universities on Facebook and Instagram.

Taking into account the differences, the results of the research revealed that universities post more on Facebook (7000 posts) than on Instagram (305 posts). On Facebook, universities focus their communication strategy on news and announcements (132), which are followed by posts about research projects (80), about events (74), admission (52), pandemic context information (51), sustainable development (41), career guidance, and competitions alike (22) (Table 1).

On Instagram, the communication strategy is focused more on providing information about related institutions and about the experiences of students. Hence, universities focused mainly on promoting related institutions (32), then on posting student testimonials (30), news and announcements posts (28), posts about the city (22), posts which contained information about the pandemic context (21), and posts about the campus (20) (Table 1).

Given the communication strategies of universities, from the perspective of the eight most common types of content, similarities are observed in the case of news and announcement posts, sustainable development, virus and vaccine information, and admission, as universities have chosen to include this type of content in their communication strategy on both Facebook and Instagram. Even more, information about the virus and the vaccine was communicated on platforms almost to the same extent (51 posts compared to 21, with an average number of posts/month of 0.7 ), and this can also be seen in the case of posts about sustainable development.

Taking into account the number of posts, universities make more posts about news and announcements on Facebook (103) than on Instagram (28). In the case of admission posts, there are more posts on Facebook (52) than on Instagram (19) (Table 1). In this regard, it can be said that on Facebook, universities focus more than on Instagram, on providing up-to-date information, administrative information, or admission information.

Differences can be seen in the case of posts about research projects. On Facebook there were 80 posts about research projects, and on Instagram there were only 11. It can be stated that, on Facebook, universities promote their research projects more than on Instagram. Also, on Facebook, universities focused more than on Instagram on providing students with information about career guidance (22 posts versus 1$)$ and information about competitions (22 posts versus 9) (Table 1).

The promotion in connection with the city is also different on the two social networks. Posts about the city are among the most common types of content used on Instagram, while on Facebook, the city is not promoted frequently. In other words, universities promote the city they belong to more on Instagram (22 posts) than on Facebook (14 posts). From the perspective of similarities, it was observed that posts about entertainment are posted less frequently both on Facebook (13 posts) and on Instagram (11 posts) (Table 1).

In terms of the format of the posts, similarly, universities use the photo format the most, both on Facebook (299) and Instagram (245) (Table 2). On the other hand, due the tools and options they integrate, differences were found in the case of the format of sharing associated or unassociated pages. Instagram does not count and does not allow users to publicly share posts on their timeline. Thus, on Facebook there are also posts with which associated or unassociated pages, are shared, but being a difference rendered by the options of the platforms, we did not consider it significant.

From the perspective of performance, the results showed that universities post more on Facebook than on Instagram. On Facebook, the universities posted with a frequency of 1.1 posts/day, while on Instagram, they had a frequency of 0.5 posts per day. However, the 
results revelead that unversities register a higher level of engagement on Instagram than on Facebook (Table 3).

Taking into account the hypotheses of the research, we next present the results in relation to each hypothesis.

The hypothesis 1 was confirmed, the results of the research showing that the universities analyzed posted more frequently on Facebook (1.1 posts per day) than on Instagram (0.5 posts per day) (Table 3 ).

The hypothesis 2 was confirmed because, all universities included in the research had a higher level of engagement on Instagram than on Facebook (Table 4). Also, from the perspective of the average number of reactions (likes) and comments, it can be seen from Table 3 that universities receive greater appreciation on Instagram (1870.44 appreciations/posts) and comments (16.97 comments) than reactions (131.5 reactions/post) and comments (5.6 comments/post) on Facebook.

The hypothesis 3 was only partially confirmed, as student testimonials were the second-most posted type of content on Instagram. There were 30 posts with student testimonials, but they were very close in number to the most-posted content, namely related institutions/spaces (32) (Table 1).

The hypothesis 4 was not confirmed. The type of content most frequently posted by the universities on Facebook was news and announcements (103), and there were very few posts regarding student counseling (11) (Table 1).

The hypothesis 5 was confirmed. The results of the research, presented in Table 2 show that the format most used by the universities analyzed on the two platforms was the photo format (299 posts with photos on Facebook, and 244 posts with photos on Instagram).

The hypothesis 6 was confirmed. The findings of the research revealed that the universities analyzed focused on various and different types of content on the two platforms. For example, on Facebook universities posted most frequently about news and announcements (132 posts), or research projects ( 80 posts), while on Instagram they focused more on promoting their related institutions and spaces (32 posts), and the experiences of students, through student testimonials (30 posts) (Table 1$)$.

\section{Discussion}

The results of our research revealed that there are differences and similarities between the way European universities communicate on their Facebook and Instagram accounts. Taking into account the platform used most by universities, our research is in line with previous studies [52] which revealed that universities preferred to communicate and promote themselves more on Facebook. Thus, from the total of 1005 posts analyzed, 700 were made by universities on Facebook.

From the perspective of the post format, similar to previous studies [49,55], our research also showed that the format most frequently used by universities was the photo format, and that universities focused more on posting visual content. Hence, we related the findings of our research to the findings of a previous study conducted in 2016 which showed that at that time, the video format was used only by $8 \%$ of the universities analyzed. In this regard, it should be taken into account that since then, the preferences of people and of institutions changed, especially in the last 2 years, meaning that the video content started to receive more attention, and thus, the results of our study should be considered while having in mind these aspects. However, distinctly from a previous study that shows that the most common type of content used on Instagram by universities was the one related to the achievements of universities [54], our research revealed that the content posted most frequently on this platform was the one about related institutions and spaces.

From the perspective of the type of content, on Facebook, the universities analyzed focused their communication strategy more on posting news and announcements, on promoting their research projects, events, admission and career guidance. On Instagram, the focus was on promoting more their related spaces and institutions, such as the library, botanical gardens, on promoting the experiences of students through testimonials, and on 
promoting the city and the campus. In terms of competitions, sustainability and information about the pandemic context, such content was promoted on Facebook and Instagram almost to the same extent.

Referring to the pandemic context, the posts mainly provided information about the prevention measures implemented, about test centers, but also about the vaccine. The University of Oxford had a significantly higher number of such posts (17 posts), which indicates that it may have been more directly involved in vaccine development projects, than other universities.

In the context of sustainability messages, our findings revealed that universities preferred to use the social network Facebook more in order to promote the sustainable development actions they carried out. In other word, their communication strategy on Facebook focused more on sending sustainability messages than it focused on Instagram. According to our research, the post about sustainability were mostly represented by post in which universities presented their plans to go net zero, or the projects they developed in order to protect the environment, such as building zero-emission boats, or developing recycling programs or competitions. Thus, the universities which posted most frequently information about their sustainable actions, was KU-Leuven on Facebook and Aalto University on Instagram. Hence, by highlighting that the universities analyzed focused mostly on posts related to environmental sustainability, our research is in line with previous studies [92].

Regarding the format most frequently used, it was represented by the photo format on Facebook (299 posts), as well as on Instagram (244 posts), and in terms of performance, the frequency of posts was higher on Facebook than on Instagram. However, higher engagement rates were registered on Instagram, even though generally, the platform was used less than Facebook. University of Oxford was the one university which registered most posts on both Facebook and Instagram, while Pompeu Fabra University was the one who had the lowest frequency of posts on Facebook, and University of Luxembourg was the one who posted most rarely on Instagram.

Furthermore, an analysis of universities situated in the same country was also conducted. Considering the four universities from the United Kingdom included in the research, by looking at their activity on Facebook and Instagram, some similarities and differences can be identified. In the context of the type of content most frequently posted on Facebook, a similarity can be seen in the case of three universities from the United Kingdom. Hence, University of Oxford, Imperial College London, and University College London posted most frequently about news and announcements. However, a difference can be seen if we compare these universities with the University of Cambridge, which posted most frequently about its research projects (Appendix B Table A2 Analysis on Facebook of the first 10 universities analyzed).

From the perspective of the type of format mostly used on Facebook, a similarity was identified between University of Oxford and University of Cambridge, both of them using most frequently the "link to the official website" format (University of Oxford-28 posts) and University of Cambridge-19 posts) (Appendix B Table A2 Analysis on Facebook of the first 10 universities analyzed). A similarity was also identified in the case of Imperial College London and University College London, which used most frequently the photo format (Imperial College London-18 posts and University College London, 5 posts). However, it must be mentioned that University of College London also had 5 posts with the "link to the official website" format.

From the perspective of the performance indicators of the four universities on Facebook, University of Oxford was the one with the highest frequency of posts in the period analyzed, followed by Imperial College London, University of Cambridge, and University College London. (Appendix B Table A2 Analysis on Facebook of the first 10 universities analyzed). Taking into account the engagement rates of the universities on Facebook, the highest engagement rate was registered by University of Oxford (0.019), and the lowest engagement rate was registered by University College London (0.004) (Table 4). Comparing 
the engagement registered on the two platforms analyzed, all four universities had higher engagement rates on Instagram than on Facebook.

Considering the activity of the four universities on Instagram, some differences were identified. University of Oxford posted most frequently about news and announcements (as it did on Facebook), University of Cambridge focused on promoting its related spaces and institutions (thus, it adopted a different approach on Instagram than on Facebook), Imperial College London focused more on presenting students' testimonials, and University College London was the one with the fewest posts (4), them being mostly about wishes and related spaces, or campus. In the context of performance indicators, the university which posted most frequently was University of Oxford, followed by University of Cambridge, Imperial College London, and University College London.

Taking into account the five Romanian universities included in the research, in the context of their activity on Facebook, the analysis revealed differences in the type of content posted most frequently. Bucharest Academy of Economic Studies, posted most often about news and announcements, Babes-Bolyai University and University of Bucharest posted mostly about events, "Alexandru Ioan Cuza" University of Iasi posted most frequently about the admission process, and Transilvania University of Brasov posted most often about career guidance (Appendix B Table A2 Analysis on Facebook of the next 10 universities analyzed).

In the context of the format most used on Facebook, all Romanian universities used most frequently the photo format. Next, considering the performance indicators, the analysis showed that "Alexandru Ioan Cuza" University of Iasi was the one that registered the highest frequency of posts, followed by Babes-Bolyai University, University of Bucharest, Transilvania University of Brasov, and Bucharest Academy of Economic Studies. Regarding the engagement rate on Facebook, the scores for the Romanian universities were similar, them having from 1 post/day-Bucharest Academy of Economic Studies to 1.63 posts/day- "Alexandru Ioan Cuza" University of Iasi. Furthermore, the highest engagement rate was registered in the case of Bucharest Academy of Economic Studies.

Taking into account the activity of the universities on Instagram, in terms of the type of content posted most frequently, the analysis revealed that compared to Facebook, on Instagram all Romanian universities promote themselves poorly. However, in spite of their poor promotion, the engagement rate was higher on Instagram in the case of all five universities. This result suggests that the audience is willing to interact more with the content that Romanian universities post on Instagram, and thus, they should focus more on improving their communication and promotion on this platform.

Hence, while some similarities were found in the activity of universities within the same country, in the case of Romanian universities as well as in the case of universities from the United Kingdom, the analysis revealed that they used different communication and promotion strategies and that they focus on different content on the two platforms analyzed.

Furthermore, taking into account the communication and promotion strategies of the universities analyzed, a series of key differences were found. In this regard, considering the type of content on which universities mostly focused on, the research revealed that European universities such as University of Oxford, ETH Zurich, Technical University Munchen, or Aalto University focused their communication strategies more on sending sustainability messages and on promoting their sustainable actions, than universities from Romania. Another noteworthy difference was found in the case of posts about podcasts, the universities which most focused on promoting such type of content being the universities from the United Kingdom, including University of Oxford, University of Cambridge, Imperial College London. Next, differences can be seen in the communication strategies of universities in the context of promoting their research projects. The universities with high positions in the ranking, such as University of Oxford, ETH Zurich, or University of Bologna, chose to concentrate their strategies on communicating information about the research projects developed and their results, while universities with lower positions, such as universities from Romania including University of Bucharest, or "Alexandru Ioan Cuza" 
University of Iasi, did not focus on describing their research on their official Facebook and Instagram pages.

However, on Facebook, the content which was promoted by all the universities included in the analysis except KU-Leuven, was news and announcements. On Instagram, the type of content promoted most was on related institutions and spaces, with University of Cambridge being the university who posted most frequently photos of its related institutions/colleges. Moreover, students' testimonials were also at the center of the promotion strategies of universities on Instagram, the universities which focused most on describing the experiences of students being Lund University, Wageningen University \& Research, or Imperial College London.

When comparing the activity of Romanian universities and the other European universities, the findings of the research showed that Romanian universities have communication strategies which involve mostly sending information about the admission process, events, news and announcements, or students' achievements.

In the context of the format used by universities, the photo format was preferred by most of the universities analyzed, with it being used the most by "Alexandru Ioan Cuza" University of Iasi in 41 posts, followed by Trinity College Dublin with 35 posts with a photo format. In terms of performance indicators, the university that posted most frequently on both Facebook and Instagram was University of Oxford, but the university that registered the highest engagement rate on the two platforms was Bucharest Academy of Economic Studies.

Therefore, the universities included in the research had diverse communication strategies, they preferred to use the social network Facebook more than Instagram, and European universities had more complex strategies than Romanian universities, with the former having posts with more varied types of content.

\section{Conclusions}

In the context of the COVID-19 pandemic, higher education institutions have faced many challenges, as they have had to adapt to the online environment, both the educational process and the way they promote themselves and communicate with students and potential students. In this regard, the purpose of our paper was to identify the promotion strategies used by European universities on Facebook and Instagram in the context of the COVID-19 pandemic.

The results of our research revealed that universities promote themselves more on Facebook than on Instagram, but they register a higher engagement rate on Instagram. This might happen due to the fact that young people today are orientated more towards visual content, and since young people are the main users of platforms such as Instagram, but also the main audience of universities, the chance of them interacting with the universities' posts is higher on Instagram than on Facebook.

Regarding the differences between the communication process of European universities on the two platforms, our research revealed that on Facebook, the strategy is focused more on posts about news and announcements, but also on promoting their research projects, events, and the admission process. On the other hand, on Instagram, the strategy is focused on promoting their related institutions and spaces, on highlighting the experience of students through testimonials, and also on promoting the city and the campus.

In terms of sustainability messages, they were posted almost with the same frequency on Facebook and on Instagram and they were mostly represented by posts which emphasized the way universities try to protect the environment, through actions such as going net zero or recycling.

Similarities in the promotion strategies used by universities on Facebook and Instagram were also found in the case of information about the pandemic context, meaning that such information was mostly almost with the same frequency on both platforms. However, although posts about the virus and about the vaccine were among the most posted types of content, it can be stated that universities have tried not to put an emphasis only on the crisis 
situation. Thus, their communication strategies included diversified content through which universities have not only sought to maintain a favorable relationship with students, but also with potential students. Furthermore, the research also revealed universities tended towards visual content, with the format most used being the photo format.

Taking into account the theoretical and practical implications of our study, from a theoretical point of view, our research contributes to the literature on the promotion and communication of universities on social networks, by providing relevant information about the elements that represented the focus of the communication strategies of European universities in the context of the pandemic. Even more, by highlighting the sustainability messages sent by universities on social networks, our study provides an overview of the way such institutions chose to promote the activities they carry out in order to protect the environment.

Furthermore, considering the theoretical implications, the paper supports the idea that universities should focus more on promoting their activity on social networks by using more visual content, as the platform Instagram, which is more orientated towards visual content, registered higher engagement rates than Facebook, and also supports the idea that in the context of sustainability, universities focus more on posts related to environmental sustainability or renewable energy. Another theoretical implication of the paper is related to the categories according to which the universities were analyzed. Hence, while at the basis of our research we had two previous studies $[49,50]$, our paper provides a wide range of types of content posted, and of types of formats. In other words, while taking into account the models used by previous studies for the analysis of universities, we added to those models, categories referring to the type of content (university achievements, alumni achievements, related institutions/spaces), or to the type of format of the posts (external link, share of associated pages, share of un-associated pages).

Regarding the practical implications, the results of our study could be used as a frame of reference in the development of communication and promotion strategies on social networks of higher education institutions. For example, universities could focus on posting more on Instagram, since the engagement rate seems to be higher on this platform than on Facebook, or they could focus their Instagram strategy on promoting students' experiences and their Facebook strategy on promoting sustainable actions and research projects.

\section{Limitations and Future Research Directions}

While our research provides relevant information on the activity on Facebook and Instagram of European universities, it also has some limitations. One limitation is represented by the fact that the activity of the universities was analyzed only for a period of one month (April 2021), while another limitation is given by the number of universities included in the study. Hence, future research should extend the analysis period and should focus on examining more universities.

Furthermore, another limitation of the study is the fact that the opinion of students or potential students about the way they communicate with the universities was not examined. In this regard, future research should also focus on analyzing the opinion of the beneficiaries.

Other future research directions would be to assess the activity of universities on more social networks, including YouTube or TikTok, to develop a comparative analysis depending on the geographical area in which universities are situated, or a comparative analysis depending on the position in the ranking of each university, and future research should focus more on the sustainability messages of universities and their role in the communication strategies of such institutions.

Author Contributions: Conceptualization, C.C., F.N. and M.C.B.; methodology: M.C.B., F.N., C.C. and G.M.; software: M.C.B. and F.N.; validation: C.C., L.S., G.M., A.O., F.N. and M.C.B.; formal analysis: M.C.B., F.N., A.O. and L.S.; investigation M.C.B., F.N. and C.C.; resources, M.C.B., F.N., G.M. and L.S.; data curation, C.C., F.N., A.O. and M.C.B.; writing-original draft preparation, M.C.B., F.N and C.C.; writing-review and editing, M.C.B., F.N., C.C., A.O., L.S. and G.M.; visualization, C.C., 
F.N. and M.C.B.; supervision, C.C. and F.N.; project administration, C.C., F.N. and M.C.B. All authors have read and agreed to the published version of the manuscript.

Funding: This research received no external funding.

Institutional Review Board Statement: Not applicable.

Informed Consent Statement: Not applicable.

Conflicts of Interest: The authors declare no conflict of interest.

\section{Appendix A}

Table A1. The Research Instrument.

\begin{tabular}{|c|c|}
\hline 1. Categories Referring to the Type of Content & $\begin{array}{c}\text { Name of the University and } \\
\text { Number of Posts }\end{array}$ \\
\hline \multicolumn{2}{|l|}{ Information about COVID-19 } \\
\hline \multicolumn{2}{|l|}{ Information about vaccine } \\
\hline \multicolumn{2}{|l|}{ Events } \\
\hline \multicolumn{2}{|l|}{ University achievements } \\
\hline \multicolumn{2}{|l|}{ Competitions } \\
\hline \multicolumn{2}{|l|}{ Research } \\
\hline \multicolumn{2}{|l|}{ Research about COVID-19 } \\
\hline \multicolumn{2}{|l|}{ Admission } \\
\hline \multicolumn{2}{|l|}{ Community involvement } \\
\hline \multicolumn{2}{|l|}{ News and announcements } \\
\hline \multicolumn{2}{|l|}{ Entertainment } \\
\hline \multicolumn{2}{|l|}{ Students' achievements } \\
\hline \multicolumn{2}{|l|}{ Graduates' achievements } \\
\hline \multicolumn{2}{|l|}{ Teachers' achievements } \\
\hline \multicolumn{2}{|l|}{ Connex institutions/spaces } \\
\hline \multicolumn{2}{|l|}{ Study/internship mobilities } \\
\hline \multicolumn{2}{|l|}{ Webinars } \\
\hline \multicolumn{2}{|l|}{ Student counselling } \\
\hline \multicolumn{2}{|l|}{ Academic conferences } \\
\hline \multicolumn{2}{|l|}{ Career guidance } \\
\hline \multicolumn{2}{|l|}{ Posts about the city } \\
\hline \multicolumn{2}{|l|}{ Campus } \\
\hline \multicolumn{2}{|l|}{ Sustainability messages } \\
\hline \multicolumn{2}{|l|}{ Students' testimonials } \\
\hline \multicolumn{2}{|l|}{ Teachers' testimonials } \\
\hline \multicolumn{2}{|l|}{ Podcast } \\
\hline \multicolumn{2}{|l|}{ Thank you messages } \\
\hline \multicolumn{2}{|l|}{ Wishes } \\
\hline Total of posts & \\
\hline
\end{tabular}


Table A1. Cont.

\section{Categories Referring to the Format of the Posts}

\begin{tabular}{c} 
Link to the official website \\
External link \\
\hline Own video \\
\hline External video \\
Photo \\
\hline Share of associated pages \\
\hline Share of unassociated pages \\
\hline Gif \\
\hline Boomerang \\
\hline Medium nr. of posts/day for the 20 univ. analyzed \\
\hline Medium nr. of reactions/post (like, love, happy, sad) \\
\hline Medium nr. of comments/post \\
\hline Medium nr. of shares/post \\
\hline Medium nr. of views/video post \\
\hline Medium nr. of page likes/of followers
\end{tabular}

\section{Appendix B. The Analysis of the Activity on Facebook of the 20 Universities Analyzed}

Table A2. Analysis on Facebook of the first 10 universities analyzed.

\begin{tabular}{|c|c|c|c|c|c|c|c|c|c|c|}
\hline $\begin{array}{l}\text { 1. Categories } \\
\text { Referring to the Type } \\
\text { of Content }\end{array}$ & $\begin{array}{l}\text { Univ. } \\
\text { Ox. }\end{array}$ & $\begin{array}{l}\text { Univ. } \\
\text { Cam. }\end{array}$ & ICL & ETH & UCL & $\begin{array}{l}\text { TU } \\
\text { Mun. }\end{array}$ & $\begin{array}{c}\text { KU } \\
\text { Leuv. }\end{array}$ & $\begin{array}{l}\text { Wag. } \\
\text { Univ. }\end{array}$ & $\begin{array}{l}\text { Lund } \\
\text { Univ. }\end{array}$ & UPF \\
\hline $\begin{array}{l}\text { Information about } \\
\text { COVID-19 }\end{array}$ & 5 & 1 & 2 & 2 & - & 4 & - & - & - & - \\
\hline $\begin{array}{l}\text { Information about } \\
\text { vaccine }\end{array}$ & 12 & - & 2 & 2 & - & - & - & - & - & - \\
\hline Events & 3 & - & 3 & 4 & 1 & 3 & 1 & 1 & - & - \\
\hline $\begin{array}{c}\text { University } \\
\text { achievements }\end{array}$ & - & - & 1 & 2 & 1 & 1 & - & - & 1 & - \\
\hline Competitions & 2 & 2 & 1 & - & - & 1 & 1 & 1 & - & 1 \\
\hline Research & 9 & 11 & 4 & 10 & - & 5 & 6 & - & 3 & - \\
\hline $\begin{array}{l}\text { Research about } \\
\text { COVID-19 }\end{array}$ & 5 & 1 & - & 1 & - & 1 & - & - & 1 & - \\
\hline Admission & 1 & - & 6 & - & - & 2 & - & 5 & 2 & - \\
\hline $\begin{array}{l}\text { Community } \\
\text { involvement }\end{array}$ & - & - & - & - & 1 & - & - & - & - & - \\
\hline $\begin{array}{c}\text { News and } \\
\text { announcements }\end{array}$ & 19 & 10 & 7 & 8 & 3 & 8 & - & 5 & 1 & 4 \\
\hline Entertainment & 1 & - & - & - & - & - & - & - & - & - \\
\hline Students' achievements & - & 1 & 1 & 2 & 1 & - & - & - & 1 & - \\
\hline
\end{tabular}


Table A2. Cont.

\begin{tabular}{|c|c|c|c|c|c|c|c|c|c|c|}
\hline Graduates' achievements & - & - & - & 2 & - & - & - & 1 & - & 1 \\
\hline Teachers' achievements & - & - & - & 2 & - & 1 & 1 & - & 1 & - \\
\hline $\begin{array}{c}\text { Connex } \\
\text { institutions/spaces }\end{array}$ & 5 & 2 & - & 1 & - & - & - & 1 & 1 & 2 \\
\hline $\begin{array}{c}\text { Study/internship } \\
\text { mobilities }\end{array}$ & - & - & - & - & - & - & - & - & - & - \\
\hline Webinars & - & - & 7 & 1 & 1 & 1 & - & 2 & - & - \\
\hline Student counselling & 3 & - & - & - & 1 & - & - & 3 & - & - \\
\hline Academic conferences & - & - & - & - & - & 1 & 1 & - & - & 1 \\
\hline Career guidance & - & - & - & - & - & 3 & - & - & - & - \\
\hline Posts about the city & 3 & 2 & - & - & - & - & - & - & 3 & 1 \\
\hline Campus & - & - & - & - & - & - & - & 4 & 1 & - \\
\hline Sustainability messages & 6 & - & - & 2 & - & 6 & 1 & 4 & 1 & - \\
\hline Students' testimonials & 1 & 1 & - & - & - & - & - & 4 & - & - \\
\hline Teachers' testimonials & - & - & - & - & - & - & 1 & - & - & - \\
\hline Podcast & 1 & 2 & 3 & 2 & 1 & 1 & - & - & - & - \\
\hline Thank you messages & - & - & - & - & - & - & - & - & - & - \\
\hline Wishes & 7 & - & 2 & 1 & 2 & 2 & - & - & - & - \\
\hline Total of posts & 83 & 32 & 40 & 41 & 12 & 40 & 12 & 31 & 16 & 10 \\
\hline $\begin{array}{c}\text { 2. Categories } \\
\text { Referring to the } \\
\text { Format of the Posts }\end{array}$ & $\begin{array}{l}\text { Univ. } \\
\text { Ox. }\end{array}$ & $\begin{array}{l}\text { Univ. } \\
\text { Cam. }\end{array}$ & ICL & ETH & UCL & $\begin{array}{l}\text { TU } \\
\text { Mun. }\end{array}$ & $\begin{array}{l}\text { KU } \\
\text { Leuv. }\end{array}$ & $\begin{array}{l}\text { Wag. } \\
\text { Univ. }\end{array}$ & $\begin{array}{l}\text { Lund } \\
\text { Univ. }\end{array}$ & UPF \\
\hline $\begin{array}{l}\text { Link to the } \\
\text { official website }\end{array}$ & 28 & 19 & 16 & 20 & 5 & 26 & 5 & 6 & - & - \\
\hline External link & 9 & 5 & 5 & 8 & - & 7 & 1 & 2 & 1 & - \\
\hline Own video & 20 & 4 & 1 & 3 & 3 & - & - & 5 & 2 & - \\
\hline External video & - & - & - & - & - & - & - & - & - & - \\
\hline Photo & 26 & 4 & 18 & 7 & 4 & 5 & 5 & 18 & 13 & 10 \\
\hline $\begin{array}{c}\text { Share of } \\
\text { associated pages }\end{array}$ & - & - & - & 3 & - & 1 & 1 & - & - & - \\
\hline $\begin{array}{c}\text { Share of } \\
\text { unassociated pages }\end{array}$ & - & - & - & - & - & 1 & - & - & - & - \\
\hline Gif & - & - & - & - & - & - & - & - & - & - \\
\hline Boomerang & - & - & - & - & - & - & - & - & - & - \\
\hline $\begin{array}{l}\text { 3. Categories } \\
\text { Refeering to } \\
\text { Performance }\end{array}$ & $\begin{array}{l}\text { Univ. } \\
\text { Ox. }\end{array}$ & $\begin{array}{l}\text { Univ. } \\
\text { Cam. }\end{array}$ & ICL & ETH & UCL & $\begin{array}{l}\text { TU } \\
\text { Mun. }\end{array}$ & $\begin{array}{l}\text { KU } \\
\text { Leuv. }\end{array}$ & $\begin{array}{l}\text { Wag. } \\
\text { Univ. }\end{array}$ & $\begin{array}{l}\text { Lund } \\
\text { Univ. }\end{array}$ & UPF \\
\hline $\begin{array}{l}\text { Medium nr. of } \\
\text { posts/day for the } \\
20 \text { univ. analyzed }\end{array}$ & 2.76 & 1.06 & 1.33 & 1.4 & 0.4 & 1.33 & 0.4 & 1.03 & 0.53 & 0.33 \\
\hline $\begin{array}{l}\text { Medium nr. of } \\
\text { reactions/post (like, } \\
\text { love, happy, sad) }\end{array}$ & 903,07 & $\begin{array}{l}52 . \\
34\end{array}$ & 54.97 & $\begin{array}{l}36 . \\
65\end{array}$ & $\begin{array}{l}75 . \\
83\end{array}$ & $\begin{array}{l}35 . \\
97\end{array}$ & $\begin{array}{l}43 . \\
41\end{array}$ & 59.45 & 97.56 & 5.7 \\
\hline $\begin{array}{l}\text { Medium nr. of } \\
\text { comments/post }\end{array}$ & 45.78 & 19.25 & 1.72 & 1.29 & 1.58 & 0.7 & 2.91 & 1.80 & 6.06 & - \\
\hline
\end{tabular}


Table A2. Cont.

\begin{tabular}{ccccccccccc}
\hline $\begin{array}{c}\text { Medium nr. of } \\
\text { shares/post }\end{array}$ & 72.19 & 37.5 & 3.55 & 2.8 & 3.5 & 1.97 & 3.25 & 2.64 & 6.25 & 0.8 \\
\hline $\begin{array}{c}\text { Medium nr. of } \\
\text { views/video post }\end{array}$ & 30,669 & 3600 & 864 & 680.33 & 1466.66 & - & - & 1580 & 3350 & - \\
\hline $\begin{array}{c}\text { Medium nr. of page } \\
\text { likes/of followers }\end{array}$ & 4307.154 & 2337.442 & 181.549 & 73.647 & 225.893 & 96.143 & 97.619 & 99.144 & 165.312 & 43.811 \\
\hline
\end{tabular}

Table A3. Analysis on Facebook of the next 10 universities analyzed.

\begin{tabular}{|c|c|c|c|c|c|c|c|c|c|c|}
\hline $\begin{array}{l}\text { 1. Categories } \\
\text { Referring to the Type } \\
\text { of Content }\end{array}$ & TCD & $\begin{array}{l}\text { Univ. } \\
\text { Bolog. }\end{array}$ & $\begin{array}{l}\text { TU- } \\
\text { Den }\end{array}$ & $\begin{array}{l}\text { Aalto } \\
\text { Univ. }\end{array}$ & $\begin{array}{l}\text { Univ. } \\
\text { Lux }\end{array}$ & ASE & UBB & $\begin{array}{l}\text { Uni- } \\
\text { Buc. }\end{array}$ & $\begin{array}{l}\text { Uaic } \\
\text { Iași }\end{array}$ & $\begin{array}{l}\text { Unit- } \\
\text { bv }\end{array}$ \\
\hline $\begin{array}{c}\text { Information about } \\
\text { COVID-19 }\end{array}$ & 8 & 1 & 1 & - & 2 & - & - & 1 & - & - \\
\hline Information about vaccine & 1 & - & - & - & 2 & - & - & 3 & - & 2 \\
\hline Events & 3 & 8 & 3 & 7 & 1 & 3 & 7 & 10 & 9 & 7 \\
\hline $\begin{array}{c}\text { University } \\
\text { achievements }\end{array}$ & 1 & 2 & 1 & 1 & - & 2 & 3 & - & 1 & - \\
\hline Competitions & - & 1 & 5 & - & 1 & - & 1 & 2 & 3 & - \\
\hline Research & 5 & 11 & 4 & 3 & 4 & 2 & 3 & - & - & - \\
\hline $\begin{array}{l}\text { Research about } \\
\text { COVID-19 }\end{array}$ & - & - & - & - & 1 & - & - & - & - & - \\
\hline Admission & 5 & 1 & - & 1 & 8 & 1 & - & - & 18 & 2 \\
\hline $\begin{array}{l}\text { Community } \\
\text { involvement }\end{array}$ & - & - & - & - & - & - & 1 & - & 2 & 1 \\
\hline $\begin{array}{c}\text { News and } \\
\text { announcements }\end{array}$ & 11 & 16 & 3 & 6 & 2 & 10 & 5 & 5 & 4 & 5 \\
\hline Entertainment & 1 & 2 & 1 & 2 & - & - & - & 2 & - & 4 \\
\hline Students' achievements & 1 & - & 1 & 3 & - & - & 3 & 4 & 1 & 2 \\
\hline Graduates' achievements & 1 & - & - & - & - & - & - & - & - & 1 \\
\hline Teachers' achievements & 3 & - & 3 & 2 & - & 3 & 1 & 2 & - & - \\
\hline $\begin{array}{c}\text { Connex } \\
\text { institutions/spaces }\end{array}$ & 1 & 2 & - & - & - & - & 1 & 1 & - & 1 \\
\hline $\begin{array}{l}\text { Study/internship } \\
\text { mobilities }\end{array}$ & - & 1 & - & - & - & - & 1 & - & 1 & - \\
\hline Webinars & 2 & - & 1 & - & - & - & 1 & - & 1 & - \\
\hline Student counselling & - & - & - & 2 & 2 & - & 2 & 1 & - & - \\
\hline Academic conferences & - & - & 1 & - & - & 1 & - & - & 2 & - \\
\hline Career guidance & 2 & 2 & - & 2 & - & - & 2 & - & 5 & 6 \\
\hline Posts about the city & 1 & 2 & - & - & - & - & - & 2 & - & - \\
\hline Campus & 4 & 2 & - & - & - & - & - & - & - & - \\
\hline Sustainability messages & - & 9 & 1 & 7 & 2 & - & 2 & - & - & - \\
\hline Students' testimonials & - & - & 1 & 2 & - & 2 & - & - & - & - \\
\hline Teachers' testimonials & - & - & - & - & - & - & - & - & - & - \\
\hline Podcast & 1 & - & - & - & - & - & - & - & - & - \\
\hline
\end{tabular}


Table A3. Cont.

\begin{tabular}{|c|c|c|c|c|c|c|c|c|c|c|}
\hline Thank you messages & - & - & 1 & - & - & - & - & - & - & - \\
\hline Wishes & 2 & - & - & 2 & - & 4 & 1 & 1 & 2 & 1 \\
\hline Total of posts & 53 & 60 & 28 & 39 & 25 & 30 & 34 & 33 & 49 & 32 \\
\hline $\begin{array}{l}\text { 2. Categories } \\
\text { Referring to the } \\
\text { Format of the Posts }\end{array}$ & TCD & $\begin{array}{l}\text { Univ. } \\
\text { Bolog. }\end{array}$ & $\begin{array}{l}\text { TU } \\
\text { Den. }\end{array}$ & $\begin{array}{l}\text { Aalto } \\
\text { Univ. }\end{array}$ & $\begin{array}{l}\text { Univ. } \\
\text { Lux. }\end{array}$ & ASE & UBB & $\begin{array}{l}\text { Uni- } \\
\text { Buc. }\end{array}$ & $\begin{array}{l}\text { Uaic } \\
\text { Iassi }\end{array}$ & Unitbv \\
\hline $\begin{array}{l}\text { Link to the } \\
\text { official website }\end{array}$ & - & 43 & 6 & 11 & 11 & - & 11 & 6 & 4 & - \\
\hline External link & - & - & - & 3 & - & 3 & 1 & 2 & 2 & 3 \\
\hline Own video & 18 & 5 & 5 & 5 & 2 & - & 6 & 6 & - & 1 \\
\hline External video & - & & - & - & - & 1 & - & - & - & - \\
\hline Photo & 35 & 12 & 17 & 19 & 11 & 14 & 14 & 7 & 41 & 19 \\
\hline $\begin{array}{c}\text { Share of } \\
\text { associated pages }\end{array}$ & - & - & - & - & 1 & 12 & 2 & 6 & - & 7 \\
\hline $\begin{array}{c}\text { Share of } \\
\text { unassociated pages }\end{array}$ & - & - & - & 1 & - & - & - & 6 & 2 & 2 \\
\hline Gif & - & - & - & - & - & - & - & - & - & - \\
\hline Boomerang & - & & - & - & - & - & - & - & - & - \\
\hline $\begin{array}{l}\text { 3. Categories } \\
\text { Refeering to } \\
\text { Performance }\end{array}$ & TCD & $\begin{array}{l}\text { Univ. } \\
\text { Bolog. }\end{array}$ & $\begin{array}{l}\text { TU } \\
\text { Den }\end{array}$ & $\begin{array}{l}\text { Aalto } \\
\text { Univ. }\end{array}$ & $\begin{array}{l}\text { Univ. } \\
\text { Lux. }\end{array}$ & ASE & UBB & $\begin{array}{l}\text { Uni- } \\
\text { Buc. }\end{array}$ & $\begin{array}{l}\text { Uaic } \\
\text { Iași }\end{array}$ & Unitbv \\
\hline $\begin{array}{l}\text { Medium nr. of } \\
\text { posts/day for the } \\
20 \text { univ. analyzed }\end{array}$ & 1.76 & 2 & 0.93 & 1.3 & 0.83 & 1 & 1.13 & 1.1 & 1.63 & 1.06 \\
\hline $\begin{array}{l}\text { Medium nr. of } \\
\text { reactions/post (like, } \\
\text { love, happy, sad) }\end{array}$ & 109.87 & 99.5 & 64 & 20.17 & 33.16 & 155.83 & 151.5 & 58.90 & 32.16 & 72.09 \\
\hline $\begin{array}{l}\text { Medium nr. of } \\
\text { comments/post }\end{array}$ & 6.18 & 3 & 2.42 & 0.35 & 4.44 & 4.36 & 5.41 & 1.42 & 1.93 & 1.96 \\
\hline $\begin{array}{l}\text { Medium nr. of } \\
\text { shares/post }\end{array}$ & 11.94 & 10.46 & 3.14 & 1.33 & 3.8 & 14.43 & 19.82 & 7.36 & 9.53 & 9.5 \\
\hline $\begin{array}{c}\text { Medium nr. of } \\
\text { views/video post }\end{array}$ & 3131.27 & 2887.40 & 2519 & 293.80 & 22.161 & 1300 & 2550 & 1492.16 & - & 2300 \\
\hline $\begin{array}{l}\text { Medium nr. of page } \\
\text { likes/of followers }\end{array}$ & 85.727 & 104.009 & 35.748 & 56.869 & 40.025 & 38.566 & 61.508 & 96.425 & 91.960 & 36.265 \\
\hline
\end{tabular}

\section{Appendix C. The Analysis of the Activity on Instagram of the 20 Universities Analyzed}

Table A4. Analysis on Instagram of the first 10 universities analyzed.

\begin{tabular}{|c|c|c|c|c|c|c|c|c|c|c|}
\hline $\begin{array}{l}\text { 1. Categories } \\
\text { Referring to the Type } \\
\text { of Content }\end{array}$ & $\begin{array}{c}\text { Univ. } \\
\text { Ox. }\end{array}$ & $\begin{array}{l}\text { Univ. } \\
\text { Cam. }\end{array}$ & ICL & ETH & UCL & $\begin{array}{l}\text { TU } \\
\text { Mun. }\end{array}$ & $\begin{array}{l}\text { KU } \\
\text { Leuv. }\end{array}$ & $\begin{array}{l}\text { Wag. } \\
\text { Univ. }\end{array}$ & $\begin{array}{l}\text { Lund } \\
\text { Univ. }\end{array}$ & UPF \\
\hline $\begin{array}{c}\text { Information about } \\
\text { COVID-19 }\end{array}$ & 3 & 1 & - & - & - & 1 & - & - & - & 1 \\
\hline Information about vaccine & 7 & - & - & - & - & 1 & - & - & - & - \\
\hline Events & 1 & - & 1 & - & - & 1 & - & - & - & - \\
\hline
\end{tabular}


Table A4. Cont.

\begin{tabular}{|c|c|c|c|c|c|c|c|c|c|c|}
\hline $\begin{array}{c}\text { University } \\
\text { achievements }\end{array}$ & - & - & - & - & - & 1 & - & 1 & - & - \\
\hline Competitions & 1 & 1 & 2 & 1 & - & - & 1 & - & - & 1 \\
\hline Research & 6 & - & - & - & - & - & 1 & 1 & - & - \\
\hline $\begin{array}{l}\text { Research about } \\
\text { COVID-19 }\end{array}$ & 3 & - & - & - & - & - & - & - & - & - \\
\hline Admission & 1 & - & 2 & - & - & - & - & 3 & 2 & - \\
\hline $\begin{array}{l}\text { Community } \\
\text { involvement }\end{array}$ & - & - & - & - & - & - & - & - & - & - \\
\hline $\begin{array}{c}\text { News and } \\
\text { announcements }\end{array}$ & 14 & 4 & - & 1 & - & 1 & - & 2 & - & 2 \\
\hline Entertainment & 1 & - & - & - & - & - & - & 4 & 1 & - \\
\hline Students' achievements & - & 3 & - & - & - & - & - & - & - & 1 \\
\hline Graduates' achievements & 1 & - & - & - & - & - & - & 1 & - & - \\
\hline Teachers' achievements & - & 2 & - & 1 & - & 2 & - & - & - & - \\
\hline $\begin{array}{c}\text { Connex } \\
\text { institutions/spaces }\end{array}$ & 6 & 9 & 1 & - & 1 & - & - & 2 & - & 3 \\
\hline $\begin{array}{c}\text { Study/internship } \\
\text { mobilities }\end{array}$ & - & - & - & - & - & - & - & - & - & - \\
\hline Webinars & - & - & - & - & - & - & - & - & - & - \\
\hline Student counselling & 4 & - & - & 1 & - & - & - & 2 & 1 & - \\
\hline Academic conferences & - & - & - & - & - & - & 1 & - & - & - \\
\hline Career guidance & - & - & - & - & - & - & - & - & - & - \\
\hline Posts about the city & 4 & 4 & 1 & 1 & - & - & - & 2 & 2 & 1 \\
\hline Campus & - & - & 3 & - & 1 & 3 & - & 10 & - & 1 \\
\hline Sustainability messages & 3 & 1 & - & 1 & - & 2 & 2 & 3 & - & - \\
\hline Students' testimonials & 2 & 2 & 5 & - & - & 2 & - & 5 & 9 & 1 \\
\hline Teachers' testimonials & - & 1 & - & - & - & - & 1 & - & - & - \\
\hline Podcast & - & - & - & - & - & - & - & - & - & - \\
\hline Thank you messages & - & - & - & - & - & - & - & - & - & - \\
\hline Wishes & 5 & - & - & - & 2 & 2 & - & 1 & - & 1 \\
\hline Total of posts & 62 & 28 & 15 & 6 & 4 & 16 & 6 & 37 & 15 & 12 \\
\hline $\begin{array}{c}\text { 2. Categories } \\
\text { Referring to the } \\
\text { Format of the Posts }\end{array}$ & $\begin{array}{l}\text { Univ. } \\
\text { Ox. }\end{array}$ & $\begin{array}{l}\text { Univ. } \\
\text { Cam. }\end{array}$ & ICL & ETH & UCL & $\begin{array}{c}\text { TU } \\
\text { Mun. }\end{array}$ & $\begin{array}{l}\text { KU } \\
\text { Leuv. }\end{array}$ & $\begin{array}{l}\text { Wag. } \\
\text { Univ. }\end{array}$ & $\begin{array}{l}\text { Lund } \\
\text { Univ. }\end{array}$ & UPF \\
\hline $\begin{array}{l}\text { Link to the official } \\
\text { website }\end{array}$ & - & - & - & - & - & - & - & - & - & - \\
\hline External link & - & - & - & - & - & - & - & - & - & - \\
\hline Own video & 21 & 1 & 1 & 1 & - & 1 & - & 13 & - & 3 \\
\hline External video & - & - & - & - & - & - & - & - & - & - \\
\hline Photo & 41 & 27 & 14 & 5 & 4 & 14 & 6 & 24 & 15 & 9 \\
\hline $\begin{array}{c}\text { Share of } \\
\text { associated pages }\end{array}$ & - & - & - & - & - & - & - & - & - & - \\
\hline $\begin{array}{c}\text { Share of } \\
\text { unassociated pages }\end{array}$ & - & - & - & - & - & - & - & - & - & - \\
\hline
\end{tabular}


Table A4. Cont.

\begin{tabular}{|c|c|c|c|c|c|c|c|c|c|c|}
\hline Gif & - & - & - & - & - & - & - & - & - & - \\
\hline Boomerang & - & - & - & - & - & 1 & - & - & - & - \\
\hline $\begin{array}{l}\text { 3. Categories } \\
\text { Refeering to } \\
\text { Performance }\end{array}$ & $\begin{array}{l}\text { Univ. } \\
\text { Ox. }\end{array}$ & $\begin{array}{l}\text { Univ. } \\
\text { Cam. }\end{array}$ & ICL & ETH & UCL & $\begin{array}{l}\text { TU } \\
\text { Mun. }\end{array}$ & $\begin{array}{c}\text { KU } \\
\text { Leuv. }\end{array}$ & $\begin{array}{l}\text { Wag. } \\
\text { Univ. }\end{array}$ & $\begin{array}{l}\text { Lund } \\
\text { Univ. }\end{array}$ & UPF \\
\hline $\begin{array}{l}\text { Medium nr. of } \\
\text { posts/day for the } \\
20 \text { univ. analyzed }\end{array}$ & 2.06 & 0.93 & 0.5 & 0.2 & 0.13 & 0.53 & 0.2 & 1.23 & 0.5 & 0.4 \\
\hline $\begin{array}{l}\text { Medium nr. of } \\
\text { reactions/post (like, } \\
\text { love, happy, sad) }\end{array}$ & 6505.85 & $11,689.96$ & 1271.26 & 1545.16 & 3552.50 & 1934 & 297.33 & 722.86 & 1064.46 & 528 \\
\hline $\begin{array}{l}\text { Medium nr. of } \\
\text { comments/post }\end{array}$ & 61.61 & 82.39 & 13.73 & 45 & 28 & 5.75 & 3.5 & 15.18 & 17.73 & 2.33 \\
\hline $\begin{array}{l}\text { Medium nr. of } \\
\text { shares/post }\end{array}$ & - & - & - & - & - & - & - & - & - & - \\
\hline $\begin{array}{c}\text { Medium nr. of } \\
\text { views/video post }\end{array}$ & 5173.6 & 35,778 & 6913 & 6881 & - & 8184.5 & - & 5836.8 & - & 3224 \\
\hline $\begin{array}{l}\text { Medium nr. of page } \\
\text { likes/of followers }\end{array}$ & $937 \mathrm{k}$ & $992 k$ & $87.2 \mathrm{k}$ & $59.4 \mathrm{k}$ & $122 \mathrm{k}$ & $44.4 \mathrm{k}$ & $29.6 \mathrm{k}$ & $37.9 \mathrm{k}$ & $34.6 \mathrm{k}$ & $20.5 \mathrm{k}$ \\
\hline
\end{tabular}

Table A5. Analysis on Instagram of the next 10 universities analyzed.

\begin{tabular}{|c|c|c|c|c|c|c|c|c|c|c|}
\hline $\begin{array}{l}\text { 1. Categories } \\
\text { Referring to the Type } \\
\text { of Content }\end{array}$ & TCD & $\begin{array}{l}\text { Univ. } \\
\text { Bolog. }\end{array}$ & $\begin{array}{l}\text { TU. } \\
\text { Den. }\end{array}$ & $\begin{array}{l}\text { Aalto. } \\
\text { Univ. }\end{array}$ & $\begin{array}{l}\text { Univ. } \\
\text { Lux. }\end{array}$ & TASE & UBB & $\begin{array}{l}\text { Uni- } \\
\text { Buc. }\end{array}$ & $\begin{array}{l}\text { Uaic } \\
\text { Iași }\end{array}$ & Unitbv \\
\hline $\begin{array}{l}\text { Information about } \\
\text { COVID-19 }\end{array}$ & - & - & - & 2 & - & 3 & - & - & - & - \\
\hline Information about vaccine & 1 & - & - & - & - & - & - & 1 & - & - \\
\hline Events & 1 & 1 & 4 & 2 & - & 2 & - & - & - & 1 \\
\hline $\begin{array}{c}\text { University } \\
\text { achievements }\end{array}$ & 1 & - & - & 1 & - & - & - & - & - & - \\
\hline Competitions & - & - & 2 & - & - & - & - & - & - & - \\
\hline Research & 2 & - & - & 1 & - & - & - & - & - & - \\
\hline $\begin{array}{l}\text { Research about } \\
\text { COVID-19 }\end{array}$ & - & - & - & - & - & - & - & - & - & - \\
\hline Admission & - & - & - & 3 & 1 & 1 & - & - & 6 & - \\
\hline $\begin{array}{l}\text { Community } \\
\text { involvement }\end{array}$ & - & - & - & - & - & - & 1 & - & - & - \\
\hline $\begin{array}{c}\text { News and } \\
\text { announcements }\end{array}$ & 1 & 1 & - & 2 & - & - & - & - & - & - \\
\hline Entertainment & - & - & 1 & 4 & - & - & - & - & - & - \\
\hline Students' achievements & 3 & - & - & 2 & - & - & - & - & - & 1 \\
\hline Graduates' achievements & - & - & - & - & - & - & - & - & - & - \\
\hline Teachers' achievements & 1 & - & - & 1 & - & - & - & - & - & - \\
\hline $\begin{array}{c}\text { Connex } \\
\text { institutions/spaces }\end{array}$ & 2 & 2 & - & - & - & - & 3 & 2 & - & 1 \\
\hline
\end{tabular}


Table A5. Cont.

\begin{tabular}{|c|c|c|c|c|c|c|c|c|c|c|}
\hline $\begin{array}{l}\text { Study/internship } \\
\text { mobilities }\end{array}$ & - & - & - & - & - & - & - & - & - & - \\
\hline Webinars & - & - & - & - & - & - & 1 & - & - & - \\
\hline Student counselling & - & - & - & 3 & 1 & - & 1 & - & - & - \\
\hline Academic conferences & - & - & 1 & - & - & - & - & - & - & - \\
\hline Career guidance & - & - & - & 1 & - & - & - & - & - & - \\
\hline Posts about the city & 1 & 6 & - & - & - & - & - & - & - & - \\
\hline Campus & 2 & - & - & - & - & - & - & - & - & - \\
\hline Sustainability messages & - & 2 & - & 6 & - & - & - & - & - & - \\
\hline Students' testimonials & - & - & 1 & 3 & - & - & - & - & - & - \\
\hline Teachers' testimonials & - & - & - & 1 & - & - & - & - & - & - \\
\hline Podcast & - & - & - & 3 & - & - & - & - & - & - \\
\hline Thank you messages & - & - & 1 & - & - & - & - & - & - & - \\
\hline Wishes & 1 & - & - & 2 & - & - & - & 1 & 1 & 1 \\
\hline Total of posts & 16 & 12 & 10 & 37 & 2 & 6 & 6 & 4 & 7 & 4 \\
\hline $\begin{array}{c}\text { 2. Categories } \\
\text { Referring to the } \\
\text { Format of the Posts }\end{array}$ & TCD & $\begin{array}{l}\text { Univ. } \\
\text { Bolog. }\end{array}$ & $\begin{array}{l}\text { TU. } \\
\text { Den. }\end{array}$ & $\begin{array}{l}\text { Aalto } \\
\text { Univ. }\end{array}$ & $\begin{array}{l}\text { Univ. } \\
\text { Lux. }\end{array}$ & ASE & UBB & $\begin{array}{l}\text { Uni- } \\
\text { Buc. }\end{array}$ & $\begin{array}{l}\text { Uaic } \\
\text { Iași }\end{array}$ & Unitbv \\
\hline $\begin{array}{c}\text { Link to the } \\
\text { official website }\end{array}$ & - & - & - & - & - & - & - & - & - & - \\
\hline External link & - & - & - & - & - & - & - & - & - & - \\
\hline Own video & 3 & - & 2 & 11 & - & 1 & - & 1 & - & - \\
\hline External video & - & - & - & - & - & - & - & - & - & - \\
\hline Photo & 13 & 12 & 7 & 26 & 2 & 5 & 6 & 3 & 7 & 4 \\
\hline $\begin{array}{c}\text { Share of } \\
\text { associated pages }\end{array}$ & - & - & - & - & - & - & - & - & - & - \\
\hline $\begin{array}{c}\text { Share of } \\
\text { unassociated pages }\end{array}$ & - & - & - & - & - & - & - & - & - & - \\
\hline Gif & - & - & 1 & - & - & - & - & - & - & - \\
\hline Boomerang & - & - & - & - & - & - & - & - & - & - \\
\hline $\begin{array}{l}\text { 3. Categories } \\
\text { Refeering to } \\
\text { Performance }\end{array}$ & TCD & $\begin{array}{l}\text { Univ. } \\
\text { Bolog. }\end{array}$ & $\begin{array}{l}\text { TU. } \\
\text { Den. }\end{array}$ & $\begin{array}{l}\text { Aalto } \\
\text { Univ. }\end{array}$ & $\begin{array}{l}\text { Univ. } \\
\text { Lux. }\end{array}$ & ASE & UBB & $\begin{array}{l}\text { Uni- } \\
\text { Buc. }\end{array}$ & $\begin{array}{l}\text { Uaic. } \\
\text { Iași }\end{array}$ & Unitbv \\
\hline $\begin{array}{l}\text { Medium nr. of } \\
\text { posts/day for the } \\
20 \text { univ. analyzed }\end{array}$ & 0.53 & 0.4 & 0.33 & 1.23 & 0.06 & 0.2 & 0.2 & 0.13 & 0.23 & 0.13 \\
\hline $\begin{array}{l}\text { Medium nr. of } \\
\text { reactions/post (like, } \\
\text { love, happy, sad) }\end{array}$ & 1527.81 & 4698.38 & 290.80 & 29.97 & 825.5 & 74.16 & 118.33 & 531.75 & 41.14 & 159.75 \\
\hline $\begin{array}{l}\text { Medium nr. of } \\
\text { comments/post }\end{array}$ & 11.06 & 15.75 & 2 & 4.75 & 27 & 0 & 0.06 & 2 & 0 & 0 \\
\hline $\begin{array}{l}\text { Medium nr. of } \\
\text { shares/post }\end{array}$ & - & - & - & - & - & - & - & - & - & - \\
\hline $\begin{array}{c}\text { Medium nr. of } \\
\text { views/video post }\end{array}$ & 5659 & - & 3207 & 1927 & - & 151 & - & 463 & - & - \\
\hline $\begin{array}{l}\text { Medium nr. of page } \\
\text { likes/of followers }\end{array}$ & $48.7 \mathrm{k}$ & $90.2 \mathrm{k}$ & $12.2 \mathrm{k}$ & $31.5 \mathrm{k}$ & $14 \mathrm{k}$ & 477 & 5338 & 7285 & 3230 & 3100 \\
\hline
\end{tabular}




\section{References}

1. Susi-Ari, K.; Herliana, N.; Hanifah, S. The Perception of Role and Responsibilities during Covid-19 Pandemic: A Survey from Indonesian Pharmacists. Int. J. Pharm. Res. 2020, 12, 3034-3039. [CrossRef]

2. Listings of WHO's Response to COVID-19. Available online: https://www.who.int/news/item/29-06-2020-covidtimeline (accessed on 19 May 2021).

3. Reddy, B.V.; Gupta, A. Importance of Effective Communication during COVID-19 Infodemic. J. Fam. Med. Prim. Care 2020, 9 , 3793-3796. [CrossRef] [PubMed]

4. Tsao, S.-F.; Chen, H.; Tisseverasinghe, T.; Yang, Y.; Li, L.; Butt, Z.A. What Social Media Told Us in the Time of COVID-19: A Scoping Review. Lancet Digit. Health 2021, 3, e175-e194. [CrossRef]

5. González-Padilla, D.A.; Tortolero-Blanco, L. Social Media Influence in the COVID-19 Pandemic. Int. Braz. J. Urol. Off. J. Braz. Soc. Urol. 2020, 46, 120-124. [CrossRef]

6. Appel, G.; Grewal, L.; Hadi, R.; Stephen, A.T. The Future of Social Media in Marketing. J. Acad. Mark. Sci. 2020, 48, 79-95. [CrossRef]

7. Wong, A.; Ho, S.; Olusanya, O.; Antonini, M.V.; Lyness, D. The Use of Social Media and Online Communications in Times of Pandemic COVID-19. J. Intensive Care Soc. 2021, 22, 255-260. [CrossRef]

8. Nguyen, M.H.; Gruber, J.; Fuchs, J.; Marler, W.; Hunsaker, A.; Hargittai, E. Changes in Digital Communication During the COVID-19 Global Pandemic: Implications for Digital Inequality and Future Research. Soc. Media Soc. 2020, 6, 2056305120948255. [CrossRef]

9. Online Education Trends Report. Available online: https://res.cloudinary.com/highereducation/image/upload/v1614724944/ BestColleges.com/edutrends/2021-Online-Trends-in-Education-Report-BestColleges.pdf (accessed on 20 May 2021).

10. Susanto, H.; Fang Yie, L.; Mohiddin, F.; Rahman Setiawan, A.A.; Haghi, P.K.; Setiana, D. Revealing Social Media Phenomenon in Time of COVID-19 Pandemic for Boosting Start-Up Businesses through Digital Ecosystem. Appl. Syst. Innov. 2021, 4, 6. [CrossRef]

11. Alshaketheep, K.M.K.I.; Salah, A.A.; Alomari, K.M.; Khaled, A.S.D.; Jray, A.A.A. Digital Marketing during COVID 19: Consumer's Perspective. WSEAS Trans. Bus. Econ. 2020, 17, 831-841. [CrossRef]

12. Carpenter, S.; Takahashi, B.; Cunningham, C.; Lertpratchya, A.P. Climate and Sustainability I The Roles of Social Media in Promoting Sustainability in Higher Education. Int. J. Commun. 2016, 10, 4863-4881.

13. Ogohi, C.D. Effects of Marketing Strategies on Organizational Performance. Int. J. Bus. Mark. Manag. 2018, 3, 1-9.

14. Alexandrescu, M.-B.; Milandru, M. Promotion as a Form of Communication of the Marketing Strategy. Land Forces Acad. Rev. 2018, 23, 268-274. [CrossRef]

15. Kotler, P.; Keller, K.L.; Brady, M.; Goodman, M.; Hansen, T. Marketing Management; Prentice Hall: Harlow, UK; New York, NY, USA, 2009; ISBN 978-0-273-71856-7.

16. Owen, R.; Humphrey, P. The Structure of Online Marketing Communication Channels. J. Manag. Mark. Res. 2010, 2, 1-10.

17. Pachitanu, A. Communication in the Digital Era and Online Corporate Communications Strategies-Untapped Opportunities for Businesses in Romania. East. Eur. Bus. Econ. J. 2016, 2, 27-42.

18. Constantinides, E.; Stagno, M.C.Z. Potential of the Social Media as Instruments of Higher Education Marketing: A Segmentation Study. J. Mark. High. Educ. 2011, 21, 7-24. [CrossRef]

19. Safko, L. The Social Media Bible: Tactics, Tools, and Strategies for Business Success; John Wiley \& Sons: Hoboken, NJ, USA, 2010; ISBN 978-0-470-62397-8.

20. Sambyal, E.; Taranpreet, K. Online Marketing Communication. Biz Bytes 2017, 8, 132-138

21. Pan, Y.; Torres, I.M.; Zúñiga, M.A. Social Media Communications and Marketing Strategy: A Taxonomical Review of Potential Explanatory Approaches. J. Internet Commer. 2019, 18, 73-90. [CrossRef]

22. Motameni, R.; Nordstrom, R. Correlating the Social Media Functionalities to Marketing Goals and Strategies. J. Mark. Manag. JMM 2014, 2, 4. [CrossRef]

23. Collin, P.; Rahilly, K.; Richardson, I.; Third, A. The Benefits of Social Networking Service: Literature Review; Cooperative Research Centre for Young People, Technology and Wellbeing: Melbourne, Australia, 2011. Available online: https://researchdirect. westernsydney.edu.au/islandora/object/uws:11520 (accessed on 20 May 2021).

24. Carr, C.T.; Hayes, R.A. Social Media: Defining, Developing, and Divining. Atl. J. Commun. 2015, 23, 46-65. [CrossRef]

25. Jothi, P.S.; Neelamalar, M.; Prasad, R.S. Analysis of Social Networking Sites: A Study on Effective Communication Strategy in Developing Brand Communication. J. Media Commun. Stud. 2011, 3, 234-242. [CrossRef]

26. Looy, A.V. Social Media Management: Technologies and Strategies for Creating Business Value, 1st ed.; 2016th ed.; Springer: Cham, Switzerland, 2015; ISBN 978-3-319-21989-9.

27. Boyd, D.; Ellison, N. Social Network Sites: Definition, History, and Scholarship. J. Comput.-Mediat. Commun. 2007, 13, 210-230. [CrossRef]

28. Liccardi, I.; Ounnas, A.; Pau, R.; Massey, E.; Kinnunen, P.; Lewthwaite, S.; Midy, M.-A.; Sarkar, C. The Role of Social Networks in Students' Learning Experiences. SIGCSE Bull. 2007, 39, 224-237. [CrossRef]

29. Hruska, J.; Maresova, P. Use of Social Media Platforms among Adults in the United States-Behavior on Social Media. Societies 2020, 10, 27. [CrossRef]

30. Chan-Olmsted, S.M.; Cho, M.; Lee, S. User Perceptions of Social Media: A Comparative Study of Perceived Characteristics and User Profiles by Social Media. Online J. Commun. Media Technol. 2013, 3, 149-178. [CrossRef] 
31. Hu, H.; Lin, D. Feature Analysis of the Social Media; Atlantis Press: Dordrecht, The Netherlands, 2013; pp. $186-190$.

32. Kemp, S. Digital 2020: Global Digital Overview. Available online: https://datareportal.com/reports/digital-2020-global-digitaloverview (accessed on 21 May 2021).

33. Edosomwan, S.; Prakasan, S.K.; Kouame, D.; Watson, J.; Seymour, T. The History of Social Media and Its Impact on Business. J. Appl. Manag. Entrep. 2011, 16, 79-91.

34. Ivala, E.; Gachago, D. Social Media for Enhancing Student Engagement: The Use of Facebook and Blogs at a University of Technology. S. Afr. J. High. Educ. 2012, 26, 152-167. [CrossRef]

35. Brügger, N. A Brief History of Facebook as a Media Text: The Development of an Empty Structure. First Monday 2015, 20. [CrossRef]

36. Douglas, N.K.M.; Scholz, M.; Myers, M.A.; Rae, S.M.; Elmansouri, A.; Hall, S.; Border, S. Reviewing the Role of Instagram in Education: Can a Photo Sharing Application Deliver Benefits to Medical and Dental Anatomy Education? Med. Sci. Educ. 2019, 29, 1117-1128. [CrossRef]

37. Salomon, D. Moving on from Facebook: Using Instagram to Connect with Undergraduates and Engage in Teaching and Learning. Coll. Res. Libr. News 2013, 74, 408-412. [CrossRef]

38. Baruah, T.D. Effectiveness of Social Media as a Tool of Communication and Its Potential for Technology Enabled Connections: A Micro-Level Study. Int. J. Sci. Res. Publ. 2012, 2, 1-10.

39. Schlagwein, D.; Hu, M. How and Why Organisations Use Social Media: Five Use Types and Their Relation to Absorptive Capacity. J. Inf. Technol. 2017, 32, 194-209. [CrossRef]

40. Cawsey, T.; Rowley, J. Social Media Brand Building Strategies in B2B Companies. Mark. Intell. Plan. 2016, 34, 754-776. [CrossRef]

41. Constantinides, E. Foundations of Social Media Marketing. Procedia-Soc. Behav. Sci. 2014, 148, 40-57. [CrossRef]

42. Bilgin, Y. The Effect of Social Media Marketing Activities on Brand Awareness, Brand Image and Brand Loyalty. Bus. Manag. Stud. Int. J. 2018, 6, 128-148. [CrossRef]

43. Wesseling, N. How Students Use Facebook. In Proceedings of the WEI International European Academic Conference Proceedings, Zagreb, Croatia, 14-17 October 2012; West Indian Institute: Zagreb, Croatia, 2012; pp. 20-25.

44. Perez, M.; Gomez, J. Why Do People Use Social Networks? Commun. IIMA 2014, 11, 41-50.

45. Alhabash, S.; Ma, M. A Tale of Four Platforms: Motivations and Uses of Facebook, Twitter, Instagram, and Snapchat Among College Students? Soc. Media Soc. 2017, 3, 2056305117691544. [CrossRef]

46. Knight-McCord, J.; Cleary, D.; Grant, N.; Herron, A.; Lacey, T.; Livingston, T.; Robinson, S.; Smith, R.; Emanuel, R. What Social Media Sites Do College Students Use Most? J. Undergrad. Ethn. Minor. Psychol. 2016, 2, 21-26.

47. Pringle, J.; Fritz, S. The University Brand and Social Media: Using Data Analytics to Assess Brand Authenticity. J. Mark. High. Educ. 2019, 29, 19-44. [CrossRef]

48. Bélanger, C.H.; Bali, S.; Longden, B. How Canadian Universities Use Social Media to Brand Themselves. Tert. Educ. Manag. 2014, 20, 14-29. [CrossRef]

49. Peruta, A.; Shields, A.B. Social Media in Higher Education: Understanding How Colleges and Universities Use Facebook. J. Mark. High. Educ. 2016, 27, 131-143. [CrossRef]

50. Peruta, A.; Shields, A.B. Marketing Your University on Social Media: A Content Analysis of Facebook Post Types and Formats. J. Mark. High. Educ. 2018, 28, 175-191. [CrossRef]

51. Zailskaitè-Jakštè, L.; Kuvykaite, R. Implementation of Communication in Social Media by Promoting Studies at Higher Education Institutions. Eng. Econ. 2012, 23, 174-188. [CrossRef]

52. Valerio-Ureña, G.; Herrera-Murillo, D.; Madero-Gómez, S. Analysis of the Presence of Most Best-Ranked Universities on Social Networking Sites. Informatics 2020, 7, 9. [CrossRef]

53. Stuart, E.; Stuart, D.; Thelwall, M. An Investigation of the Online Presence of UK Universities on Instagram. ONLINE Inf. Rev. 2017, 41, 582-597. [CrossRef]

54. Maresova, P.; Hruška, J.; Kuca, K. Social Media University Branding. Educ. Sci. 2020, 10, 74. [CrossRef]

55. Ayman, U.; Kaya, A.K.; Kuruç, Ü.K. The Impact of Digital Communication and PR Models on the Sustainability of Higher Education during Crises. Sustainability 2020, 12, 8295. [CrossRef]

56. AI-Youbi, A.O.; Al-Hayani, A.; Bardesi, H.J.; Basheri, M.; Lytras, M.D.; Aljohani, N.R. The King Abdulaziz University (KAU) Pandemic Framework: A Methodological Approach to Leverage Social Media for the Sustainable Management of Higher Education in Crisis. Sustainability 2020, 12, 4367. [CrossRef]

57. Pavel, C. The growing importance of social media in business marketing. Quaestus Multidiscip. Res. J. 2015, 7, 94-98.

58. Ramsaran-Fowdar, R.R.; Fowdar, S. The Implications of Facebook Marketing for Organizations. Contemp. Manag. Res. 2013, 9 , 73-84. [CrossRef]

59. Behera, S.; Balaji, P. Social Media Marketing: Opportunities and Challenges. Int. J. Manag. Technol. Eng. 2019, 9, $5637-5648$.

60. Khan, G.F.; Swar, B.; Lee, S.K. Social Media Risks and Benefits: A Public Sector Perspective. Soc. Sci. Comput. Rev. 2014, 32, 606-627. [CrossRef]

61. Assaad, W.; Gómez, J.M. Social Network in Marketing (Social Media Marketing) Opportunities and Risks. Int. J. Manag. Public Sect. Inf. Commun. Technol. 2011, 2, 13-22. 
62. World Commission on Environment and Development. Our Common Future: Report of World Commission on Environment and Development. 1987. Available online: https://sswm.info/sites/default/files/reference_attachments/UN\%20WCED\%201987 \%20Brundtland\%20Report.pdf (accessed on 19 January 2022).

63. Godemann, J.; Michelsen, G. Sustainability Communication-An Introduction. In Sustainability Communication: Interdisciplinary Perspectives and Theoretical Foundation; Godemann, J., Michelsen, G., Eds.; Springer: Dordrecht, The Netherlands, 2011 ; pp. 3-11. ISBN 978-94-007-1697-1.

64. Cortese, A.D. The Critical Role of Higher Education in Creating a Sustainable Future. Plan. High. Educ. 2003, 31, 15-22.

65. Lozano, R.; Lukman, R.; Lozano, F.J.; Huisingh, D.; Lambrechts, W. Declarations for Sustainability in Higher Education: Becoming Better Leaders, through Addressing the University System. J. Clean. Prod. 2013, 48, 10-19. [CrossRef]

66. Barth, M. Implementing Sustainability in Higher Education: Learning in an Age of Transformation; Routledge: London, UK, 2014; ISBN 978-0-203-48835-5.

67. Amaral, L.P.; Martins, N.; Gouveia, J.B. Quest for a Sustainable University: A Review. Int. J. Sustain. High. Educ. 2015, 16, 155-172. [CrossRef]

68. Dmochowski, J.; Garofalo, D.; Fisher, S.; Greene, A.; Gambogi, D. Integrating Sustainability across the University Curriculum. Int. J. Sustain. High. Educ. 2016, 17, 652-670. [CrossRef]

69. Ávila, L.V.; Leal Filho, W.; Brandli, L.; Macgregor, C.J.; Molthan-Hill, P.; Özuyar, P.G.; Moreira, R.M. Barriers to Innovation and Sustainability at Universities around the World. J. Clean. Prod. 2017, 164, 1268-1278. [CrossRef]

70. Orecchini, F.; Valitutti, V.; Vitali, G. Industry and Academia for a Transition towards Sustainability: Advancing Sustainability Science through University-Business Collaborations. Sustain. Sci. 2012, 7, 57-73. [CrossRef]

71. Rieckmann, M. Future-Oriented Higher Education: Which Key Competencies Should Be Fostered through University Teaching and Learning? Futures 2011, 44, 127-135. [CrossRef]

72. Kioupi, V.; Voulvoulis, N. Education for Sustainable Development: A Systemic Framework for Connecting the SDGs to Educational Outcomes. Sustainability 2019, 11, 6104. [CrossRef]

73. Aleixo, A.M.; Leal, S.; Azeiteiro, U.M. Conceptualization of Sustainable Higher Education Institutions, Roles, Barriers, and Challenges for Sustainability: An Exploratory Study in Portugal. J. Clean. Prod. 2018, 172, 1664-1673. [CrossRef]

74. Purcell, W.M.; Henriksen, H.; Spengler, J.D. Universities as the Engine of Transformational Sustainability toward Delivering the Sustainable Development Goals: "Living Labs" for Sustainability. Int. J. Sustain. High. Educ. 2019, 20, 1343-1357. [CrossRef]

75. Yáñez, S.; Uruburu, Á.; Moreno, A.; Lumbreras, J. Sustainability Report as an Essential Tool for the Holistic and Strategic Vision of Higher Education Institutions. J. Clean. Prod. 2019, 207, 57-66. [CrossRef]

76. Zamora-Polo, F.; Sánchez-Martín, J. Teaching for a Better World. Sustainability and Sustainable Development Goals in the Construction of a Change-Maker University. Sustainability 2019, 11, 4224. [CrossRef]

77. Vagnoni, E.; Cavicchi, C. An Exploratory Study of Sustainable Development at Italian Universities. Int. J. Sustain. High. Educ. 2015, 16, 217-236. [CrossRef]

78. Finnveden, G.; Friman, E.; Mogren, A.; Palmer, H.; Sund, P.; Carstedt, G.; Lundberg, S.; Robertsson, B.; Rodhe, H.; Svärd, L. Evaluation of Integration of Sustainable Development in Higher Education in Sweden. Int. J. Sustain. High. Educ. 2020, 21, 685-698. [CrossRef]

79. Katiliūtè, E.; Daunorienè, A.; Katkute, J. Communicating the Sustainability Issues in Higher Education Institutions World Wide Webs. Procedia-Soc. Behav. Sci. 2014, 156, 106-110. [CrossRef]

80. Sima, M.; Grigorescu, I.; Balteanu, D. An Overview of Campus Greening Initiatives at Universities in Romania. Int. J. Sustain. High. Educ. 2019, 20, 410-422. [CrossRef]

81. Mazon, G.; Pereira Ribeiro, J.M.; Montenegro de Lima, C.R.; Castro, B.C.G.; Guerra, J.B.S.O. de A. The Promotion of Sustainable Development in Higher Education Institutions: Top-down Bottom-up or Neither? Int. J. Sustain. High. Educ. 2020, 21, 1429-1450. [CrossRef]

82. Chen, C.; Vanclay, F. Transnational Universities, Host Communities and Local Residents: Social Impacts, University Social Responsibility and Campus Sustainability. Int. J. Sustain. High. Educ. 2021, 22, 88-107. [CrossRef]

83. Karmasin, M.; Voci, D. The Role of Sustainability in Media and Communication Studies' Curricula throughout Europe. Int. J. Sustain. High. Educ. 2021, 22, 42-68. [CrossRef]

84. Rowe, D.; Winslade, A.L. Trends, Skills, and Strategies to Catalyze Sustainability across Institutions. In The Sustainable University: Green Goals and New Challenges for Higher Education Leaders; Martin, J., Samels, J.E., Eds.; Johns Hopkins University Press: Baltimore, MD, USA, 2012; pp. 32-48. ISBN 978-1-4214-0459-2.

85. Sharp, L.; Pollock, S. Institutionalizing Sustainability: Achieving Transformation from the Inside. In The Sustainable University: Green Goals and New Challenges for Higher Education Leaders; Samels, J.E., Martin, J., Eds.; Johns Hopkins University Press: Baltimore, MD, USA, 2012; pp. 63-82. ISBN 978-1-4214-0628-2.

86. Findler, F.; Schönherr, N.; Lozano, R.; Stacherl, B. Assessing the Impacts of Higher Education Institutions on Sustainable Development-An Analysis of Tools and Indicators. Sustainability 2019, 11, 59. [CrossRef]

87. Shi, H.; Lai, E. An Alternative University Sustainability Rating Framework with a Structured Criteria Tree. J. Clean. Prod. 2013, 61, 59-69. [CrossRef]

88. Ruiz-Mallén, I.; Heras, M. What Sustainability? Higher Education Institutions' Pathways to Reach the Agenda 2030 Goals. Sustainability 2020, 12, 1290. [CrossRef] 
89. Holm, T.; Sammalisto, K.; Grindsted, T.S.; Vuorisalo, T. Process Framework for Identifying Sustainability Aspects in University Curricula and Integrating Education for Sustainable Development. J. Clean. Prod. 2015, 106, 164-174. [CrossRef]

90. Hamid, S.; Ijab, M.T.; Sulaiman, H.; Anwar, R.; Norman, A.A. Social Media for Environmental Sustainability Awareness in Higher Education. Int. J. Sustain. High. Educ. 2017, 18, 474-491. [CrossRef]

91. Gori, E.; Romolini, A.; Fissi, S.; Contri, M. Toward the Dissemination of Sustainability Issues through Social Media in the Higher Education Sector: Evidence from an Italian Case. Sustainability 2020, 12, 4658. [CrossRef]

92. Pilař, L.; Kvasničková Stanislavská, L.; Pitrová, J.; Krejčí, I.; Tichá, I.; Chalupová, M. Twitter Analysis of Global Communication in the Field of Sustainability. Sustainability 2019, 11, 6958. [CrossRef]

93. Ott, H.; Wang, R.; Bortree, D. Communicating Sustainability Online: An Examination of Corporate, Nonprofit, and University Websites. Mass Commun. Soc. 2016, 19, 671-687. [CrossRef]

94. World University Rankings. Available online: https://www.timeshighereducation.com/world-university-rankings/2021/worldranking (accessed on 23 May 2021). 